\title{
Global and regional impacts of HONO on the chemical composition of clouds and aerosols
}

\author{
Y. F. Elshorbany ${ }^{1}$, P. J. Crutzen ${ }^{1}$, B. Steil ${ }^{1}$, A. Pozzer ${ }^{1}$, H. Tost $^{2}$, and J. Lelieveld ${ }^{1,3}$ \\ ${ }^{1}$ Max Planck Institute for Chemistry, Division of Atmospheric Chemistry, Mainz, Germany \\ ${ }^{2}$ Institut für Physik der Atmosphäre, Johannes Gutenberg Universität, Mainz, Germany \\ ${ }^{3}$ The Cyprus Institute, Nicosia, Cyprus \\ Correspondence to: Y. F. Elshorbany (yasin.elshorbany@mpic.de)
}

Received: 22 July 2013 - Published in Atmos. Chem. Phys. Discuss.: 9 September 2013

Revised: 26 November 2013 - Accepted: 16 December 2013 - Published: 3 February 2014

\begin{abstract}
Recently, realistic simulation of nitrous acid (HONO) based on the $\mathrm{HONO} / \mathrm{NO}_{\mathrm{x}}$ ratio of 0.02 was found to have a significant impact on the global budgets of $\mathrm{HO}_{\mathrm{x}}\left(\mathrm{OH}+\mathrm{HO}_{2}\right)$ and gas phase oxidation products in polluted regions, especially in winter when other photolytic sources are of minor importance. It has been reported that chemistry-transport models underestimate sulphate concentrations, mostly during winter. Here we show that simulating realistic $\mathrm{HONO}$ levels can significantly enhance aerosol sulphate ( $\mathrm{S}(\mathrm{VI})$ ) due to the increased formation of $\mathrm{H}_{2} \mathrm{SO}_{4}$. Even though in-cloud aqueous phase oxidation of dissolved $\mathrm{SO}_{2}$ (S(IV)) is the main source of $\mathrm{S}(\mathrm{VI})$, it appears that $\mathrm{HONO}$ related enhancement of $\mathrm{H}_{2} \mathrm{O}_{2}$ does not significantly affect sulphate because of the predominantly S(IV) limited conditions, except over eastern Asia. Nitrate is also increased via enhanced gaseous $\mathrm{HNO}_{3}$ formation and $\mathrm{N}_{2} \mathrm{O}_{5}$ hydrolysis on aerosol particles. Ammonium nitrate is enhanced in ammonia-rich regions but not under ammonia-limited conditions. Furthermore, particle number concentrations are also higher, accompanied by the transfer from hydrophobic to hydrophilic aerosol modes. This implies a significant impact on the particle lifetime and cloud nucleating properties. The HONO induced enhancements of all species studied are relatively strong in winter though negligible in summer. Simulating realistic HONO levels is found to improve the modelmeasurement agreement of sulphate aerosols, most apparent over the US. Our results underscore the importance of HONO for the atmospheric oxidizing capacity and corroborate the central role of cloud chemical processing in S(IV) formation.
\end{abstract}

\section{Introduction}

Despite improvements in the control strategies of air quality in urban areas during the last decades, reducing air pollution is still a major challenge due to the very complex chemical mechanisms and the large number of species emitted into the atmosphere. Fine aerosol particles have direct and indirect impacts on climate (e.g., Charlson et al., 1991, 1992; Haywood and Boucher, 2000; IPCC, 2007) and human health (e.g., WHO, 2002; Lelieveld et al., 2013). The aerosol radiative forcing is highly uncertain and depends on the aerosol burden and distribution (IPCC, 2007). Knowledge of aerosol chemical composition and the controlling processes are thus of paramount importance. The inorganic compounds $\mathrm{SO}_{4}^{2-}$, $\mathrm{NO}_{3}^{-}$and $\mathrm{NH}_{4}^{+}$are among the major constituents of the fine particles in polluted air, e.g., in megacities such as Beijing (Sun et al., 2013). Sulphate aerosols are primarily produced by the condensation of $\mathrm{H}_{2} \mathrm{SO}_{4}$ and the aqueous phase oxidation of dissolved gas phase $\mathrm{SO}_{2}, \mathrm{~S}(\mathrm{IV})$, by $\mathrm{O}_{3}$ and $\mathrm{H}_{2} \mathrm{O}_{2}$ (e.g., Lelieveld et al., 1997; Seinfeld and Pandis, 2006). Recently, the transition-metal-ion catalysed oxidation of S(IV) by $\mathrm{O}_{2}$ has also been highlighted as an important source especially in rural areas (Harris et al., 2013, and references therein). Cloud processing has long been known as the most important source of aerosol sulphate on regional (e.g., Seidl and Dlugi, 1991; McHenry and Dennis, 1994; Lelieveld et al., 1997; Venkataraman et al., 2001; Menegoz et al., 2009) and global scale (e.g., Hegg, 1985; Feichter et al., 1996; Liao et al., 2003), accounting for up to two thirds of ambient sulphate concentrations, with $\mathrm{H}_{2} \mathrm{O}_{2}$ being the most effective oxidant followed by $\mathrm{O}_{3}$ (e.g., Feichter et al., 1996). 
The aqueous phase oxidation of S(IV) can be either oxidant (i.e., $\mathrm{O}_{3}$ or $\mathrm{H}_{2} \mathrm{O}_{2}$ ) or $\mathrm{SO}_{2}$ limited and occurs primarily in clouds because of their relatively high liquid water content, LWC, compared to aerosol (e.g., Schwartz et al., 1987; Van den Berg et al., 2000; Seinfeld and Pandis, 2006). Under oxidant limited conditions, enhancement of the oxidant concentrations may significantly accelerate sulphate formation, in contrast to S(IV) limited conditions (e.g., Seinfeld and Pandis, 2006). Secondary aerosol formation by gas/liquid partitioning is also well recognised as an important source of aerosols (e.g., Kulmala et al., 2004). Sulphuric acid is the major contributor to atmospheric nucleation (e.g., Seidl and Dlugi, 1991; Kulmala et al., 2006; Kirkby et al., 2011; Neitola et al., 2013). Unlike sulphates, nitrates are nearly exclusively produced by the uptake of nitric acid $\left(\mathrm{HNO}_{3}\right)$ into cloud droplets and aerosols and its reaction with available ammonium and other cations. In ammonia-rich regions, enhancement of aerosol sulphate concentrations may also enhance nitrate aerosol formation via the heterogeneous $\mathrm{N}_{2} \mathrm{O}_{5}$ hydrolysis on sulphate aerosol particles forming $\mathrm{HNO}_{3}$ (e.g., Lamsal et al., 2010; L. Zhang et al., 2012). In ammonialimited regions, enhancements of sulphate can substitute nitrate and chloride ions, driving them out of the condensed phase (e.g., Seinfeld and Pandis, 2006).

During the last decades, $\mathrm{HONO}$ has been shown to play a major role in $\mathrm{HO}_{\mathrm{x}}\left(\mathrm{OH}+\mathrm{HO}_{2}\right)$ and $\mathrm{O}_{3}$ production as well as in the formation of other secondary oxidation products (e.g., Perner and Platt, 1979; Harris et al., 1982; Elshorbany et al., 2009a, b, 2010a, b, 2012a, b). Several previous localscale studies have reported an important impact of HONO photolysis on aerosol chemical composition. Goncalves et al. (2012) found that simulated $\mathrm{PM}_{2.5}$ is increased up to $14 \%$ by accounting for HONO sources in Madrid, Spain. Li et al. (2010) found that HONO sources play an important role in the formation of secondary aerosols in Mexico City, substantially enhancing their concentrations by a factor of 2 on average in the morning. They also found that the simulated particle-phase nitrate and ammonium are substantially enhanced in the morning, though the effect on sulphate aerosol was much smaller, being in good agreement with the measurements. Further, R. Zhang et al. (2012) found that HONO can enhance the daily mean $\mathrm{PM}_{2.5}$ in the Pearl River Delta, China by up to $17 \mu \mathrm{g} \mathrm{m}^{-3}(12 \%)$.

Underestimation of sulphate aerosols has been reported by several studies, especially in polluted regions, which was attributed to missing oxidation pathways, being largest in winter and relatively small in summer (e.g., Dennis et al., 1993; Roelofs et al., 1998, 2001). HONO formation mechanisms are still poorly understood and therefore it is difficult for global models to simulate realistic HONO concentrations. Recently, Elshorbany et al. (2012b) have shown that HONO levels can be realistically parameterized, being about an order of magnitude higher compared to the reference simulations that consider the reaction of $\mathrm{OH}+\mathrm{NO}$ as the sole HONO source. They also showed that HONO photolysis sig- nificantly enhances the gas phase mixing ratios of $\mathrm{H}_{2} \mathrm{O}_{2}$, $\mathrm{HNO}_{3}, \mathrm{O}_{3}$ and $\mathrm{H}_{2} \mathrm{SO}_{4}$, which play an important role in the formation of aerosols. Therefore, simulating realistic HONO levels may possibly improve the agreement between models and measurements. In this study, we investigate the impact of HONO on the aerosol physical and chemical properties and compare the simulation results with measurement data from monitoring networks.

\section{Model description}

The applied modelling system based on the ECHAM5 general circulation model (Roeckner et al., 2006) and the Modular Earth Submodel System (MESSy2, Jöckel et al., 2005, 2010) to simulates the meteorology and atmospheric chemistry. The ECHAM5/MESSy Atmospheric Chemistry (EMAC) system is a coupled lower-middle atmospheric chemistry general circulation model (AC-GCM), which has been extensively evaluated against observations (e.g., Jöckel et al., 2006; Lelieveld et al., 2007; Tost et al., 2007; Pozzer et al., 2007; 2010, 2012; Brühl et al., 2012; de Meij et al., 2012). The model structure and setup have been described by Jöckel et al. (2006) and (2010) and only a brief description is given here, focusing on aerosol related submodels.

The atmospheric aerosol is parameterized in this study using the submodel GMXe (Pringle et al., 2010; Tost and Pringle, 2012). Gas/aerosol partitioning is calculated in GMXe in two stages; kinetically (the same as that in M7 Vignati et al., 2004, but extended to $\mathrm{NH}_{3}, \mathrm{HCl}$ and $\mathrm{HNO}_{3}$ ), in which the amount of gas phase species is kinetically allowed to condense (assuming diffusion limited condensation) on aerosol particles and thermodynamically (using ISORROPIA II, Fountoukis and Nenes, 2007), in which the condensed material is redistributed between the gas and aerosol phase. The size distribution (in radius) is described by four hydrophilic (nucleation (ns, $<5 \mathrm{~nm}$ ), Aitken (ks, 5-50 nm), accumulation (as, 50-500 nm), coarse (cs, > 500 nm)) and three hydrophobic (Aitken (ki, 5-50 nm), accumulation (ai, 50$500 \mathrm{~nm}$ ), coarse (ci, > 500 nm)) interacting lognormal aerosol modes, with prognostic aerosol mass and number and a diagnosed mean radius. The aerosol compounds treated explicitly are $\mathrm{H}_{2} \mathrm{O}, \mathrm{Na}^{+}, \mathrm{Cl}^{-}, \mathrm{NH}_{4}^{+}, \mathrm{SO}_{4}^{2-}, \mathrm{NO}_{3}^{-}$and the bulk compounds of organic carbon (OC), black carbon (BC), dust and a bulk sea salt (the fraction that is not described by $\mathrm{NaCl}$ and sea salt sulphate). Dry deposition, sedimentation and wet deposition of gas and aerosol phase species are calculated using DRYDEP (dry deposition of trace gases and aerosol particles, Ganzeveld et al., 1998; Kerkweg et al., 2006), SEDI (sedimentation of aerosol particles, Kerkweg et al., 2006), and SCAV (scavenging and liquid phase chemistry in clouds and precipitation, Tost et al., 2006) submodels, respectively. SCAV calculates the uptake of trace gases and aerosol particles (radius dependent) into cloud and precipitation droplets. The wet deposition flux out of the lowest 

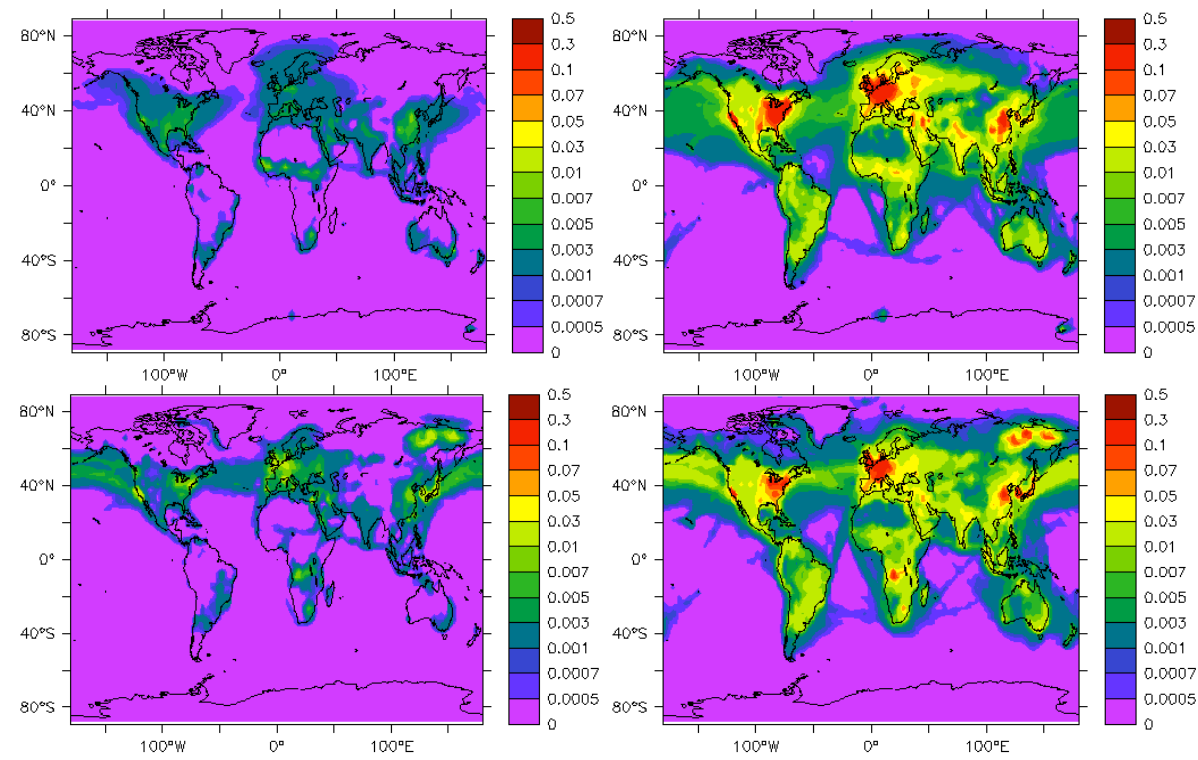

Fig. 1. Simulated monthly average HONO mixing ratios (ppbv) from the reference run (base_S1, left) and the sensitivity run (S1, i.e. using a $\mathrm{HONO} / \mathrm{NO}_{\mathrm{x}}$ ratio of 0.02 , right) near the surface in January (upper panels) and July (lower panels).

model layer represents the chemical composition of rainwater. The gas and aqueous phase chemistry, including the transfer of gaseous compounds, dissociation of acidic and alkaline species in the droplets and aqueous phase redox reactions are calculated by a coupled system of ordinary differential equations using the kinetic pre-processor (KPP) software (Sandu and Sander, 2006). The gas and the liquid phase chemical processes are fully coupled and do not require prescribed mixing ratios or $\mathrm{pH}$ values. Since usually only a small fraction of a grid box is affected by clouds and precipitation, only the cloud covered part or the part in which the precipitation occurs contributes to the scavenging, while the rest of the grid box remains unaffected. A scavenged aerosol particle can be either removed from the atmosphere by wet deposition or released through droplet evaporation (aerosols are then transferred into the largest available mode). Ions that are converted to molecules via chemical reactions in the aqueous phase can be released to the gas phase. At the end of each time step, it is assumed that the cloud completely evaporates and that all volatile species will be released to the gas phase, while the ions are transferred to the aerosol phase, thus affecting the aerosol properties: e.g., the $\mathrm{SO}_{2}$ oxidation to $\mathrm{SO}_{4}^{2-}$ can significantly increase the aerosol sulphate amount. Atmospheric gas phase chemical reactions are incorporated in the model through the module MECCA (Sander et al., $2005,2011)$. To study the effects of changes in the chemistry while avoiding possible feedbacks of radiatively active gases and aerosols through the meteorology, the radiation scheme has been decoupled, and the model is used in the atmospheric chemistry-transport mode. The radiation code in EMAC uses an ozone climatology (Fortuin and Kelder, 1998), fixed ver- tical profiles for $\mathrm{CH}_{4}, \mathrm{~N}_{2} \mathrm{O}$ and $\mathrm{CFCs}$ and constant mixing ratios of $\mathrm{CO}_{2}$.

HONO is parameterized in this study following Elshorbany et al. (2012b), in which HONO, $\mathrm{NO}_{\mathrm{x}}$ and auxiliary atmospheric chemistry parameters have been investigated using data from 15 field measurement campaigns around the globe. The high correlation between HONO and $\mathrm{NO}_{\mathrm{x}}$ in all data sets revealed a robust and consistent linear regression slope of $0.02 \pm 0.002$. Comparison with field measurements showed that, given the ambient $\mathrm{NO}_{\mathrm{x}}$ mixing ratio, the $\mathrm{HONO} / \mathrm{NO}_{\mathrm{x}}$ ratio is a suitable proxy predictor for HONO mixing ratios under different atmospheric conditions. Using a global chemistry-climate model and employing this $\mathrm{HONO} / \mathrm{NO}_{\mathrm{x}}$ ratio, realistic $\mathrm{HONO}$ levels are simulated, being about one order of magnitude higher than the reference calculations that only consider the reaction $\mathrm{OH}+\mathrm{NO} \rightarrow \mathrm{HONO}$. The resulting enhancement of HONO was found to significantly impact $\mathrm{HO}_{\mathrm{x}}$ levels and photo-oxidation products (e.g, $\mathrm{O}_{3}$, PAN), mainly in polluted regions. Furthermore, the relative enhancements in $\mathrm{OH}$ and secondary products were higher in winter than in summer, thus enhancing the oxidation capacity in polluted regions, especially in winter when other photolytic $\mathrm{OH}$ sources are of minor importance. Similar to Elshorbany et al. (2012b), HONO levels are parameterized in this study (as mentioned in the sensitivity model runs below) such that the $\mathrm{HONO} / \mathrm{NO}_{\mathrm{x}}$ ratio is fixed at 0.02 , which was achieved by an iterative correction of $\mathrm{HONO}$ and $\mathrm{NO}_{\mathrm{x}}$ (i.e., without perturbing the reactive nitrogen budget), which was applied every minute, thus limiting deviations in the $\mathrm{HONO} / \mathrm{NO}_{\mathrm{x}}$ ratio to within \pm 0.005 . 

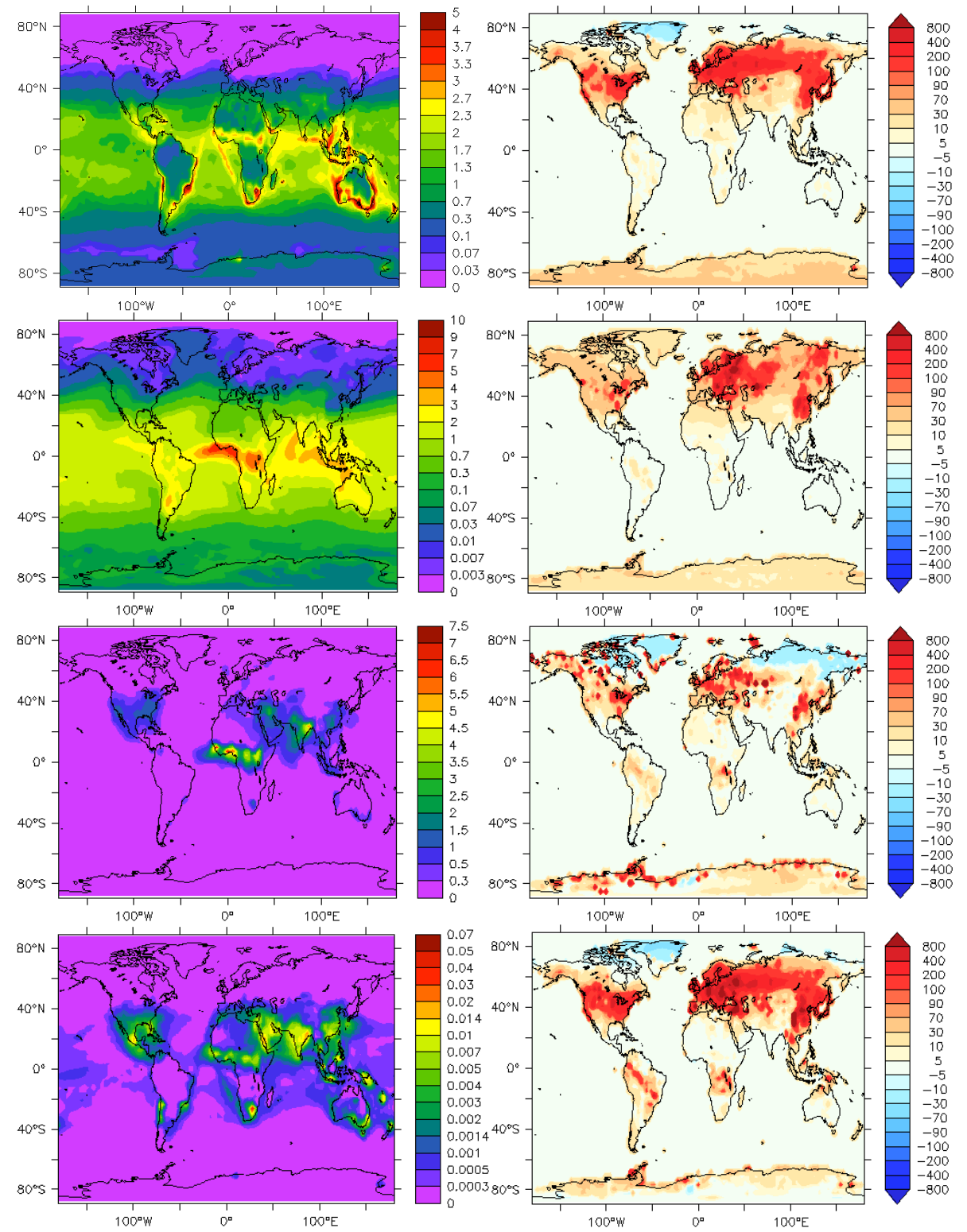

$100^{\circ} \mathrm{W} \quad \mathrm{O}^{\mathrm{O}} \quad 100^{\circ}$

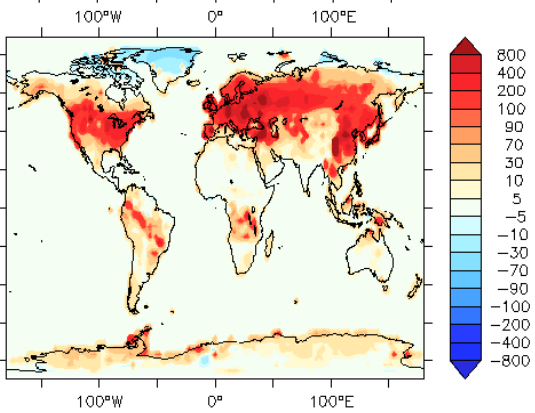

Fig. 2. Average simulated $\mathrm{OH}$ (from top to bottom) $\left(10^{6}\right.$ molecules $\left.\mathrm{cm}^{-3}\right), \mathrm{H}_{2} \mathrm{O}_{2}, \mathrm{HNO}_{3}, \mathrm{H}_{2} \mathrm{SO}_{4}$ (ppbv) near the surface from the reference run (base_S1, left panels) and their relative enhancements (\%) due to the implementation of realistic HONO levels in the model (S1, right panels) in January.

The reference run (base_S1) has been performed for the years 2000-2001 in T42L31 resolution (i.e., with a triangular truncation at wave number 42 for the spectral core of ECHAM5, and with 31 levels on a hybrid-pressure grid in the vertical, reaching up to $10 \mathrm{hPa}$ ). The T42 resolution corresponds to a quadratic Gaussian grid of approximately $2.8^{\circ} \times 2.8^{\circ}$ in latitude and longitude. To simulate realistic synoptic conditions, we applied a weak "nudging" towards actual meteorology by the assimilation of analysis data from the European Centre for Medium-range Weather Forecasting (ECMWF) through the Newtonian relaxation of four prognostic model variables: temperature, divergence, vorticity and the logarithm of surface pressure (van Aalst et al., 2004; Lelieveld et al., 2007). The first 12 months of the simulation are regarded as a spin up period and these results are not considered in our analysis. In the sensitivity run S1, HONO levels were parameterized such that the $\mathrm{HONO} / \mathrm{NO}_{\mathrm{x}}$ ratio is fixed at 0.02 , simulating realistic HONO levels (Elshorbany et al., 2012b). In order to investigate the most important process affected by the HONO enhancement in the model, four additional sensitivity runs were performed (see Table 1) base_S2, S2, base_S3 and S3. In the base_S2 and S2 sensitivity runs, only gas/liquid partitioning based on Henry' law coefficients was allowed without aqueous phase chemistry 

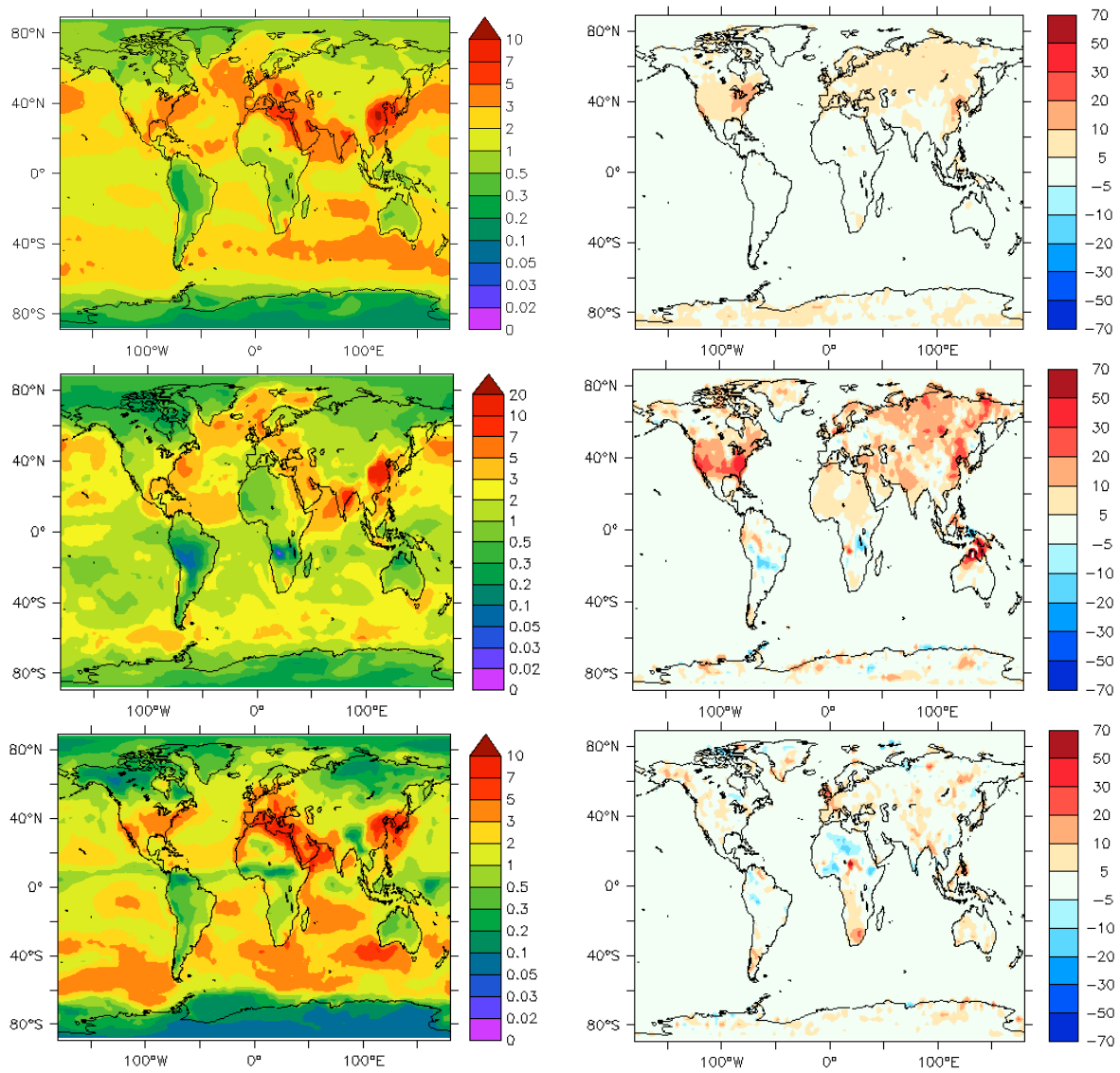

Fig. 3. Simulated aerosol sulphate concentrations $\left(\mu \mathrm{g} \mathrm{m}^{-3}\right)$ near the surface for the mean annual (upper panels), boreal winter (January, middle panels) and summer (July, lower panels) conditions from the reference run (base_S1) and relative changes (in \%, right panels) due to HONO enhancement in the model.

(similar to the "EASY" sensitivity runs in Tost et al., 2007), thus determining the impact of aqueous phase chemistry on aerosol formation in the absence (base_S2) and the presence (S2) of realistic HONO levels by comparing it to the base_S1 and S1 runs, respectively. In the base_S3 and S3 sensitivity runs, the gas phase oxidation of $\mathrm{SO}_{2}$ with $\mathrm{OH}$ results in a dummy species (i.e., $\mathrm{OH}+\mathrm{SO}_{2} \rightarrow$ DUMMY), thus masking the production of gas phase $\mathrm{H}_{2} \mathrm{SO}_{4}$. From these sensitivity runs, the impact of gas phase $\mathrm{H}_{2} \mathrm{SO}_{4}$ on the aerosol formation in the absence (base_S3) and the presence (S3) of realistic HONO levels can be determined by comparing them to the base_S1 and S1 runs, respectively.

The current study builds on the model-observation results of Elshorbany et al. (2012b) for the HONO parameterization and on the aerosol validation results of Pringle et al. (2010), Tost and Pringle (2012), de Meij et al. (2012) and Pozzer et al. (2012). Furthermore, modelling results of this study are also compared to data from monitoring networks (see Sect. 4.2 and Table 5).

\section{Measurement networks}

The simulated aerosol concentrations are compared with data from the Clean Air Status and Trends NETwork (CASTNET; Edgerton et al., 1990) for North America, the European Monitoring and Evaluation Program (EMEP; Hjellbrekke and Fjæraa, 2011) for Europe and the Acid Deposition Monitoring Network in East Asia (EANET; Totsuka et al., 2005) for Asia. The model result - measurements comparisons are performed for the simulated period in 2001, on a monthly mean basis. Only stations that cover the entire time period within each network are included, resulting in 54, 81 and 10 stations for CASTNET, EMEP and EANET, respectively. For comparison, the simulated data are sampled at the observation locations based on the respective geographical coordinates of the measuring stations.

\section{Results and discussion}

As shown in Fig. 1, the monthly mean simulated near surface HONO levels during both summer and winter are about one 

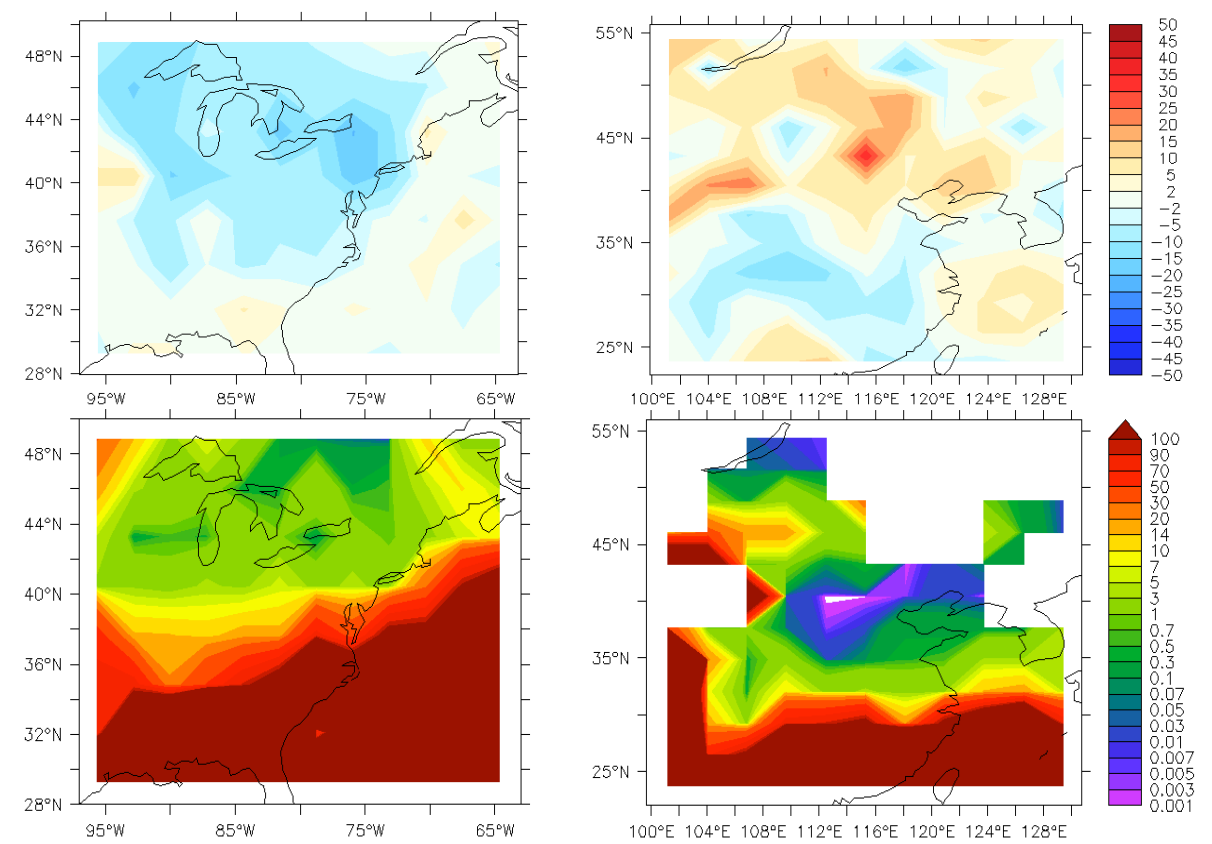

Fig. 4. Simulated monthly average relative changes (\%) of aerosol sulphate (upper panels), and the ratio of in-cloud aqueous phase concentrations of $\mathrm{H}_{2} \mathrm{O}_{2} / \mathrm{HSO}^{-}$(lower panels) in January without the gas phase oxidation of $\mathrm{SO}_{2}$ (base_S3), over the eastern US (left) and China (right).

order of magnitude higher in the S1 run than in the base_S1 run, which considers the gas phase reaction of $\mathrm{NO}$ with $\mathrm{OH}$ as the sole source of HONO, in line with our previous analysis (Elshorbany et al., 2012b). Elshorbany et al. (2012b) have shown that simulating realistic HONO levels significantly enhances the global concentrations of $\mathrm{HO}_{\mathrm{x}}$ and oxidation products in high $\mathrm{NO}_{\mathrm{x}}$ regions, especially during the winter season when other photolytic sources are of minor importance. In the next sections, we focus on the HONO impacts during the boreal winter season, while the summer and/or annual results are presented in the Supplement. In Fig. 2, the impact of the enhanced HONO levels on the simulated monthly average $\mathrm{OH}$ and the gas phase oxidation products, $\mathrm{HNO}_{3}\left(\mathrm{OH}+\mathrm{NO}_{2}\right), \mathrm{H}_{2} \mathrm{SO}_{4}\left(\mathrm{OH}+\mathrm{SO}_{2}\right)$ and $\mathrm{H}_{2} \mathrm{O}_{2}$ $\left(\mathrm{HO}_{2}+\mathrm{HO}_{2}\right)$ during winter are shown. The enhancement of $\mathrm{HONO}$ leads to increased oxidation rates by $\mathrm{OH}$ leading to enhancements of $\mathrm{O}_{3}, \mathrm{~N}_{2} \mathrm{O}_{5}$ (not shown) and $\mathrm{H}_{2} \mathrm{O}_{2}$ and also $\mathrm{HNO}_{3}$ and $\mathrm{H}_{2} \mathrm{SO}_{4}$ levels, especially during winter (Fig. 2) while in summer much smaller changes are simulated. The enhancements of $\mathrm{HNO}_{3}$ and $\mathrm{H}_{2} \mathrm{SO}_{4}$ may increase nitrate and sulphate aerosols, respectively. In addition, the enhancement of aerosol sulphate also contributes to the formation of nitrates via the heterogeneous hydrolysis of $\mathrm{N}_{2} \mathrm{O}_{5}$ forming $\mathrm{HNO}_{3}$. The uptake of $\mathrm{O}_{3}$ and $\mathrm{H}_{2} \mathrm{O}_{2}$ in clouds may enhance the aqueous oxidation of dissolved $\mathrm{SO}_{2}$ in clouds, thus increasing the oxidation rates of $\mathrm{HSO}_{3}^{-}$and $\mathrm{SO}_{3}^{2-}$ (S(IV)) to $\mathrm{S}(\mathrm{VI})$, which can be transferred to the aerosol phase upon the evaporation of the cloud droplets. However, the impact of $\mathrm{HONO}$ on the aqueous phase production of $\mathrm{S}(\mathrm{VI})$ depends on the relative abundance of S(IV) and the oxidants and does not affect sulphate concentrations under S(IV) limited conditions. In the following sections, we investigate the impact of these enhanced gas phase species on the chemical composition of aerosols.

\subsection{Impacts on aerosol chemical composition}

The major constituents of fine aerosol particles are typically organic compounds (lumped as $\mathrm{OC}$ ), water soluble ions, e.g., $\mathrm{SO}_{4}^{2-}, \mathrm{NO}_{3}^{-}$, and $\mathrm{NH}_{4}^{+}$, and mineral dust (Jimenez et al., 2009; Sun et al., 2013, and references therein). As mentioned above, daytime HONO photolysis accelerates oxidation processes, especially under high $\mathrm{NO}_{\mathrm{x}}$ conditions, which leads to increased concentrations of aerosol precursors, e.g, $\mathrm{HNO}_{3}$, $\mathrm{N}_{2} \mathrm{O}_{5}, \mathrm{H}_{2} \mathrm{SO}_{4}$ and other inorganic (e.g., $\mathrm{O}_{3}, \mathrm{H}_{2} \mathrm{O}_{2}$ ) and organic (OVOC, PAN) oxidation products, which can affect the cloud and aerosol composition.

\subsubsection{Sulphates}

As shown in Fig. 3, sulphate concentrations are higher in summer than in winter, related to the faster photochemical oxidation during summer. On the other hand, the impact of HONO is strongest during winter related to the relatively minor importance of other photolytic $\mathrm{OH}$ sources and the higher $\mathrm{NO}$ levels (i.e., conditions under which $\mathrm{OH}$ recycling is most efficient, see Sect. 4, Elshorbany et al., 2010b, 2012b). Aerosol sulphates are enhanced only in regions that are rich in both $\mathrm{NO}_{\mathrm{x}}$ and ammonia; i.e., though 

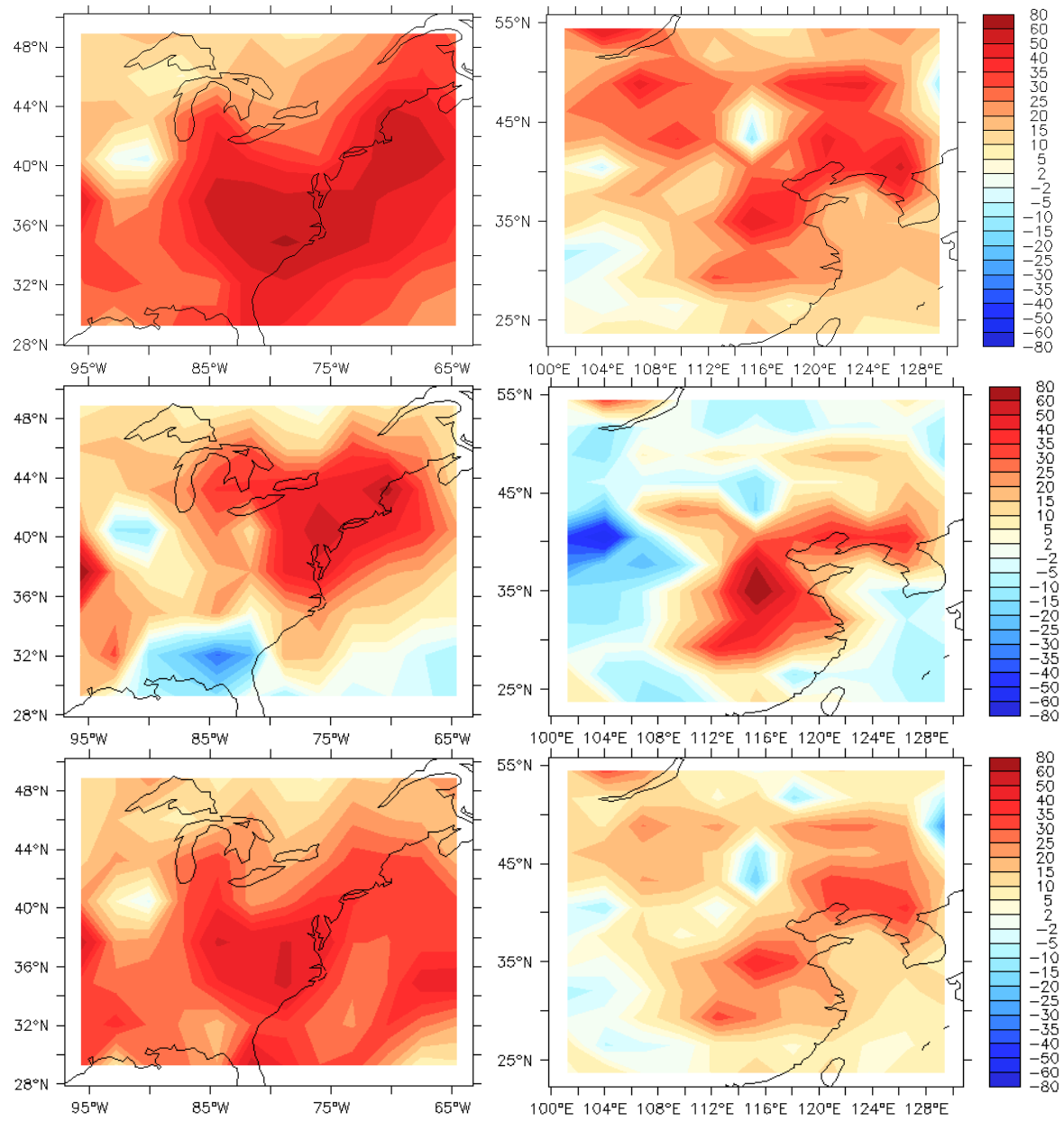

Fig. 5. Simulated monthly average relative changes (\%) in the aerosol (accumulation soluble mode, as) sulphates (upper panels), nitrates (middle panels) and ammonium (lower panels) in the reference run (base_S1) near the surface in January over the eastern US (left) and China (right) due to HONO enhancement in the model (S1).

India is an ammonia-rich region, sulphates are not significantly enhanced due to the relatively low- $\mathrm{NO}_{\mathrm{x}}$ conditions in this region (see Fig. 3). Considering the growing $\mathrm{NO}_{\mathrm{x}}$ sources in southern Asia this may change in future. The mean annual aerosol concentrations of sulphates (S(VI)) are significantly enhanced as a result of the more realistic HONO levels, reaching a mean annual relative enhancement of about $20 \%$ over the highly polluted $\mathrm{NO}_{\mathrm{x}}$-rich regions, especially over the eastern US and China. Furthermore, $\mathrm{S}(\mathrm{VI})$ is significantly enhanced during winter, reaching up to $+50 \%$ during January (Fig. 3).

As shown in Table 2, gas phase $\mathrm{H}_{2} \mathrm{SO}_{4}$ accounts for about $17-18 \%$ of the simulated total sulphate aerosol concentration while aqueous phase chemistry accounts for about 25 and $54 \%$ in January over the eastern US and China, respectively, in the base_S1 run. The remainder of the sulphate concentration is due to emissions (i.e., direct anthropogenic emissions and sea salt sulphate, see Pringle et al., 2010; Tost and Pringle, 2012). As a result of simulating realistic HONO levels (in the $\mathrm{S} 1$ run), the contribution of gas phase $\mathrm{H}_{2} \mathrm{SO}_{4}$ increases to about 30 and $26 \%$ while that of the aqueous chemistry decreases to 14 and $45 \%$ over the eastern US and China, respectively. If only chemically formed sulphates are considered, gas phase $\mathrm{H}_{2} \mathrm{SO}_{4}$ would account for about 41 and $25 \%$ of the simulated sulphate aerosol concentrations, which increases to about 68 and $37 \%$ in January over the eastern US and China, respectively, as a result of simulating realistic HONO levels (see Table 2). Thus, the relative contribution of gas phase $\mathrm{H}_{2} \mathrm{SO}_{4}$ increases by about 69 and $50 \%$ while that of the aqueous phase chemistry decreases by about 47 and $16 \%$ over the eastern US and China, respectively. A striking result is that gas phase $\mathrm{H}_{2} \mathrm{SO}_{4}$ becomes more important than aqueous phase chemistry in sulphate production over the eastern US (see Table 2).

In the absence of aqueous phase chemistry (Tables 2, S2), the enhancement of gas phase $\mathrm{H}_{2} \mathrm{SO}_{4}$ leads to about 31 and $34 \%$ enhancement over the eastern US and China, respectively. In the absence of gas phase $\mathrm{H}_{2} \mathrm{SO}_{4}$ (Table 2, 

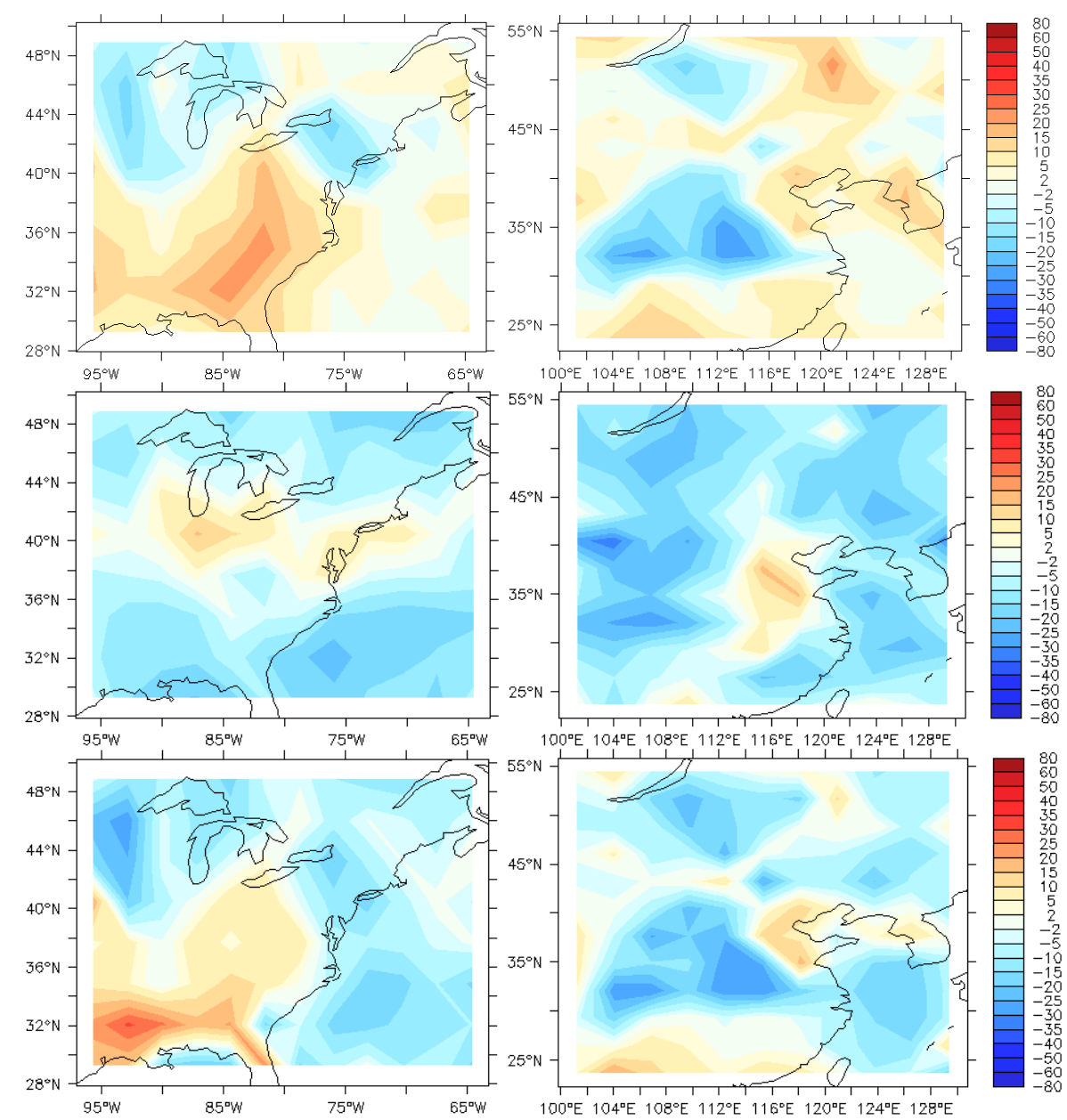

Fig. 6. Simulated monthly average relative changes (\%) in the aerosol (coarse soluble mode, cs) sulphates (upper panels), nitrates (middle panels) and ammonium (lower panels) in the reference run (base_S1) near the surface in January over the eastern US (left) and China (right) due to HONO enhancement in the model (S1).

Table 1. List of the simulation setups of the different model scenarios.

\begin{tabular}{lll}
\hline scenario & base_S & $\mathrm{S}$ \\
\hline 1 & $\begin{array}{l}\text { default setup; [HONO]pss } \\
\text { (see } S \text { Sect. } 2)\end{array}$ & $\begin{array}{l}\text { as base_S1 except } \mathrm{HONO}: \\
\text { Iterative correction of } \mathrm{HONO} / \mathrm{NO}_{\mathrm{x}} \text { ratio }=0.02\end{array}$ \\
\hline 2 & $\begin{array}{l}\text { as base_S1 except } \mathrm{SCAV}=\text { EASY: no aqueous phase chemistry, } \\
\text { i.e., only uptake of gas phase species using effective Henry's law constant }\end{array}$ & as S1 except SCAV=EASY \\
\hline 3 & $\begin{array}{l}\text { as base_S1 except } \mathrm{SO}_{2}+\mathrm{OH}=\mathrm{DUMMY}, \\
\text { i.e., no gas phase } \mathrm{H}_{2} \mathrm{SO}_{4} \text { from the oxidation of } \mathrm{SO}_{2} \text { with } \mathrm{OH} .\end{array}$ & as $\mathrm{S} 1$ except $\mathrm{SO}_{2}+\mathrm{OH}=\mathrm{DUMMY}$ \\
\hline
\end{tabular}

scenario S3), no significant sulphate enhancement is calculated. Thus, though both gas phase $\mathrm{H}_{2} \mathrm{O}_{2}$ and $\mathrm{O}_{3}$ are also enhanced as a result of simulating realistic HONO levels (Fig. 2), which subsequently increase their levels in the aqueous phase (see Supplement), they do not seem to significantly affect sulphate concentrations over the eastern US and China (see Table 2, scenario S3). This is related to the prevailing S(IV) limited conditions in most of these regions, thus any increase in the $\mathrm{H}_{2} \mathrm{O}_{2}$ concentration does not affect sulphate aerosol concentration (sf. Seinfeld and Pandis, 2006; Shen, 2011). For instance, over eastern China, in the absence of $\mathrm{H}_{2} \mathrm{SO}_{4}$ from the gas phase oxidation of $\mathrm{SO}_{2}$, enhancement in the sulphate aerosol concentration (up to $+50 \%$ ) seems to occur only when the ratio of $\mathrm{H}_{2} \mathrm{O}_{2} / \mathrm{HSO}_{3}^{-}$in the aqueous phase is below 0.1, while for ratios in excess of 1 (also over eastern US), no enhancements are calculated (Fig. 4). 
Table 2. Contributions of the different chemical processes to the simulated aerosol sulphate, nitrate and ammonium concentrations and their relative enhancement as a result of simulating realistic HONO levels during January in the eastern US and China.

\begin{tabular}{|c|c|c|c|c|c|c|c|}
\hline \multirow{2}{*}{ species } & \multirow{2}{*}{ conditions } & \multicolumn{3}{|c|}{ eastern US, $95-65^{\circ} \mathrm{W}, 30-50^{\circ} \mathrm{N}$} & \multicolumn{3}{|c|}{ eastern China, $100-130^{\circ} \mathrm{E}, 25-55^{\circ} \mathrm{N}$} \\
\hline & & base_S $\left[\mu \mathrm{g} \mathrm{m}^{-3}\right]$ & $\mathrm{S}\left[\mu \mathrm{g} \mathrm{m}^{-3}\right]$ & $\%^{\mathrm{a}}$ & base_S $\left[\mu \mathrm{g} \mathrm{m}^{-3}\right]$ & $\mathrm{S}\left[\mu \mathrm{g} \mathrm{m}^{-3}\right]$ & $\%^{\mathrm{a}}$ \\
\hline \multirow{5}{*}{ total sulphate } & S1 & 2.97 & 3.39 & 14 & 5.18 & 5.72 & 11 \\
\hline & $\mathrm{S} 2$ & 2.23 & 2.92 & 31 & 2.36 & 3.17 & 34 \\
\hline & S3 & 2.47 & 2.38 & -3.7 & 4.26 & 4.23 & -0.61 \\
\hline & $\mathrm{H}_{2} \mathrm{SO}_{4} \% \mathrm{~b}$ & 17 & 30 & & 18 & 26 & \\
\hline & Aqueous $\%$ c & 25 & 14 & & 54 & 45 & \\
\hline \multirow{2}{*}{$\begin{array}{l}\text { chemically formed } \\
\text { sulphate }\end{array}$} & $\mathrm{H}_{2} \mathrm{SO}_{4} \%$ & 41 & 68 & & 25 & 37 & \\
\hline & Aqueous $\%$ & 59 & 32 & & 75 & 63 & \\
\hline \multirow{3}{*}{ nitrate } & S1 & 2.05 & 2.23 & 8.9 & 2.51 & 2.64 & 4.9 \\
\hline & S2 & 2.41 & 2.61 & 8.4 & 3.20 & 3.25 & 1.6 \\
\hline & S3 & 1.79 & 1.89 & 5.9 & 2.40 & 2.45 & 2.4 \\
\hline \multirow{3}{*}{ ammonium } & S1 & 1.08 & 1.25 & 16 & 2.97 & 3.18 & 7.1 \\
\hline & S2 & 0.77 & 1.05 & 37 & 1.56 & 1.87 & 20 \\
\hline & S3 & 0.88 & 0.86 & -1.8 & 2.60 & 2.53 & -2.8 \\
\hline \multirow[t]{4}{*}{ number concentration } & & base_S $\left[\mathrm{cm}^{-3}\right]$ & $\mathrm{S}\left[\mathrm{cm}^{-3}\right]$ & $\%^{\mathrm{a}}$ & base_S $\left[\mathrm{cm}^{-3}\right]$ & $\mathrm{S}\left[\mathrm{cm}^{-3}\right]$ & $\%^{\mathrm{a}}$ \\
\hline & S1 & 2032 & 2242 & 10 & 5520 & 6129 & 11 \\
\hline & $\mathrm{S} 2$ & 2129 & 2675 & 26 & 5830 & 9857 & 69 \\
\hline & S3 & 1956 & 1951 & -0.26 & 5438 & 5430 & -0.15 \\
\hline
\end{tabular}

S1: basic setup, all aerosol formation processes are included, S2: no aqueous phase chemistry, i.e., only uptake of gaseous species based on Henry's law constant, S3: no gas phase production of $\mathrm{H}_{2} \mathrm{SO}_{4}$ from the oxidation of $\mathrm{SO}_{2}$ with $\mathrm{OH}$.

${ }^{a}$ Relative enhancement as a result of simulating realistic HONO levels.

${ }^{b}$ Relative contribution of the gas phase $\mathrm{H}_{2} \mathrm{SO}_{4}$, calculated from the difference between $\mathrm{S} 1$ and S3.

c Relative contribution of the aqueous phase chemistry, calculated from the difference between S1 and S2.

In Table 3, the mean simulated concentrations of sulphate, nitrate and ammonium as well as their relative enhancements due to HONO are shown for the different soluble aerosol modes during summer and winter over the eastern US and China. The corresponding figures for the accumulation and coarse modes during winter are shown in Figs. 5 and 6, respectively. The relative enhancements in the aerosol mass concentrations are dominated by the nucleation and Aitken modes while the absolute enhancements are dominated by the accumulation mode and to a lesser extent the coarse mode. Since almost no enhancement in aerosol sulphate is calculated in the absence of the gas phase oxidation of $\mathrm{SO}_{2}$ (Table 2, scenario S3), the enhancement in the larger modes is mainly related to the condensation of the enhanced gas phase $\mathrm{H}_{2} \mathrm{SO}_{4}$ as well as the coagulation of smaller particles in the nucleation and Aitken modes. Sulphate aerosol concentrations have been reported to be underestimated by models, especially during winter with much better correlation between measured and simulated sulphates during summer (Jeuken, 2000; Pringle et al., 2010; Pozzer et a., 2012; de Meij et al., 2012). This underestimation has been related to a possible lack of photochemical oxidation pathways of $\mathrm{SO}_{2}$, which, based on our results, could be due to the underestimated $\mathrm{OH}$ during winter owing to the lack of $\mathrm{HONO}$ in their simulations (see Sect. 4.2).

\subsubsection{Nitrates}

In coastal regions nitrate aerosols are predominantly found as sodium nitrate and more inland (continental) as ammonium nitrate (if there is an excess of ammonia). Nitrates are generally overestimated by models compared to reported measurements, partly owing to experimental artefacts related to nitrate sampling on quartz filters, especially in spring and summer. Nevertheless, better correlations with measurements were observed in summer compared to winter, which were partly explained by the absence of oxidation pathways (de Meij et al., 2012; Pozzer et al., 2012). In contrast to sulphates, which are produced mainly by the oxidation of $\mathrm{S}$ (IV) with $\mathrm{H}_{2} \mathrm{O}_{2}$ and $\mathrm{O}_{3}$ in clouds, nitrates are produced mainly from the transfer of gas phase nitric acid and $\mathrm{N}_{2} \mathrm{O}_{5}$ to the clouds/particles. The impact of enhanced gas phase $\mathrm{HNO}_{3}$ levels on aerosol nitrate depends on the availability of ammonia/ammonium, which is preferentially bound by $\mathrm{H}_{2} \mathrm{SO}_{4}$ /sulphate (e.g., Seinfeld and Panids, 2006). In the absence of gas phase $\mathrm{H}_{2} \mathrm{SO}_{4}$, nitrate concentrations are reduced by about 13 and $5 \%$ over eastern US and China, respectively, in the base run, which is related to the reduced surface area of sulphate aerosols allowing less condensation and hydrolysis (Table 2, S3 compared to S1). 

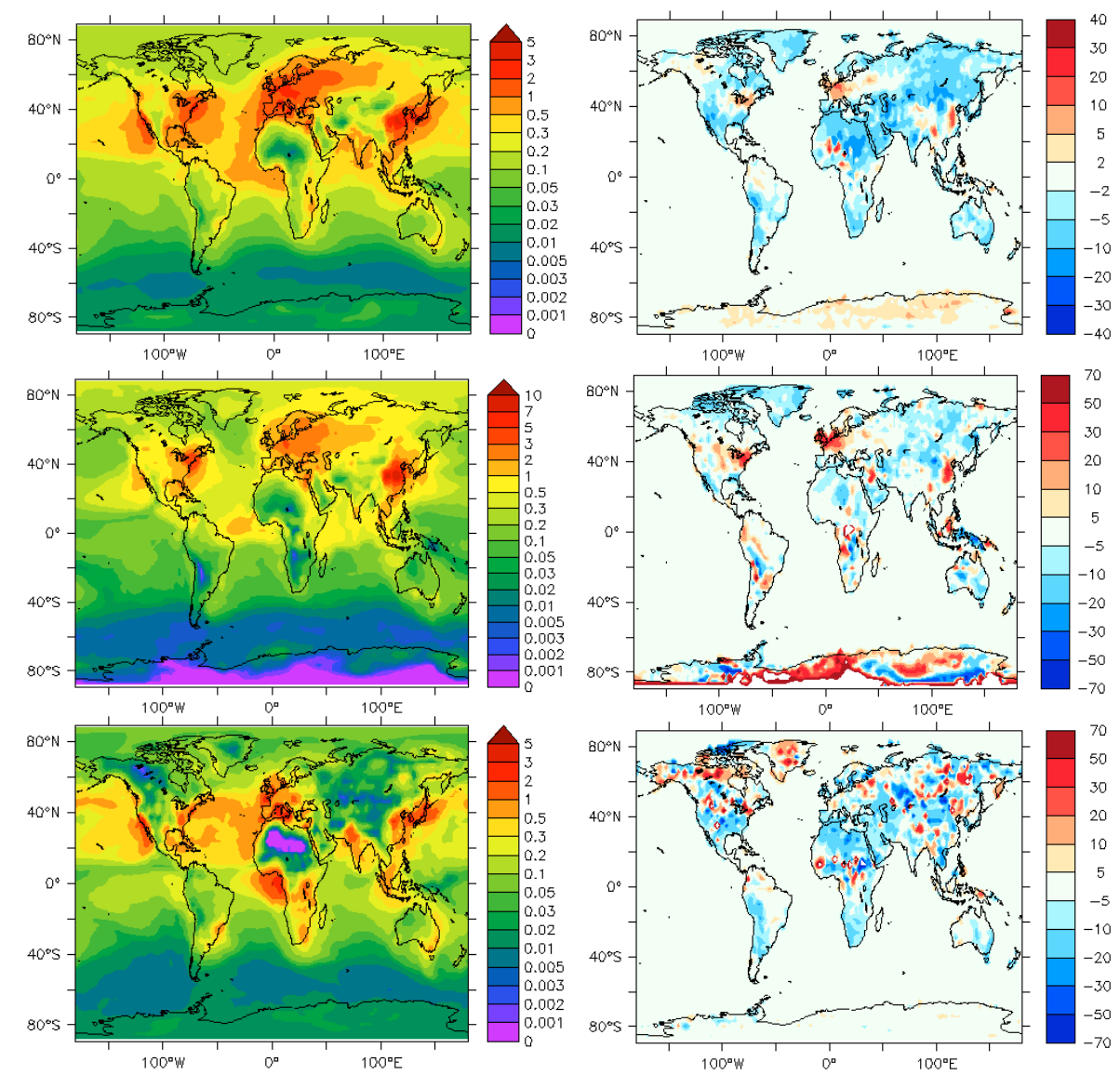

Fig. 7. Simulated aerosol nitrate concentration $\left(\mu \mathrm{g} \mathrm{m}^{-3}\right)$ near the surface for the mean annual (upper panels), boreal winter (January, middle panels) and summer (July, lower panels) conditions and relative changes (in \%, right panels) due to HONO enhancement in the model.

Table 3. Contributions of the different aerosol modes to the simulated aerosol mean sulphate, nitrate and ammonium concentrations and their relative enhancement as a result of simulating realistic HONO levels.

\begin{tabular}{|c|c|c|c|c|c|c|c|c|c|c|c|c|c|}
\hline \multirow{3}{*}{ aerosol mode } & \multirow{3}{*}{ date } & \multicolumn{4}{|c|}{ sulphate } & \multicolumn{4}{|c|}{ nitrate } & \multicolumn{4}{|c|}{ ammonium } \\
\hline & & \multicolumn{2}{|c|}{ eastern $\mathrm{US}^{1}$} & \multicolumn{2}{|c|}{ eastern China ${ }^{2}$} & \multicolumn{2}{|c|}{ eastern US ${ }^{1}$} & \multicolumn{2}{|c|}{ eastern China ${ }^{2}$} & \multicolumn{2}{|c|}{ eastern US ${ }^{1}$} & \multicolumn{2}{|c|}{ eastern China ${ }^{2}$} \\
\hline & & $\mu \mathrm{g} \mathrm{m}^{-3}$ & $\% *$ & $\mu \mathrm{g} \mathrm{m}^{-3}$ & $\% *$ & $\mu \mathrm{g} \mathrm{m}^{-3}$ & $\% *$ & $\mu \mathrm{g} \mathrm{m}^{-3}$ & $\% * \mid$ & $\mu \mathrm{g} \mathrm{m}^{-3}$ & $\% *$ & $\mu \mathrm{g} \mathrm{m}^{-3}$ & $\% *$ \\
\hline \multirow{2}{*}{$\begin{array}{l}\text { total } \\
\text { aerosol }\end{array}$} & January & 2.97 & 14 & 5.18 & 11 & 2.05 & 9 & 2.51 & 5 & 1.07 & 16 & 2.97 & 7 \\
\hline & July & 3.07 & 2 & 3.70 & 1 & 0.49 & -7 & 0.45 & -8 & 0.89 & 3 & 1.18 & 1 \\
\hline \multirow{2}{*}{ ns } & January & $6.13 \times 10^{-7}$ & 1021 & $4.74 \times 10^{-7}$ & 9090 & $8.79 \times 10^{-13}$ & 4564 & $1.56 \times 10^{-11}$ & 528353 & $1.90 \times 10^{-07}$ & 1098 & $1.59 \times 10^{-07}$ & 10303 \\
\hline & July & $7.04 \times 10^{-9}$ & -20 & $4.31 \times 10^{-8}$ & 7 & $2.85 \times 10^{-18}$ & -85 & $3.88 \times 10^{-15}$ & -100 & $1.67 \times 10^{-09}$ & -24 & $1.51 \times 10^{-08}$ & 6 \\
\hline \multirow{2}{*}{ ks } & January & $1.07 \times 10^{-2}$ & 65 & $1.47 \times 10^{-2}$ & 29 & $3.94 \times 10^{-06}$ & 134 & $1.76 \times 10^{-05}$ & 36 & $3.59 \times 10^{-03}$ & 75 & $4.79 \times 10^{-03}$ & 35 \\
\hline & July & $1.24 \times 10^{-2}$ & 1 & $2.03 \times 10^{-2}$ & 4 & $2.46 \times 10^{-12}$ & -29 & $3.43 \times 10^{-11}$ & 18 & $4.42 \times 10^{-03}$ & 3 & $6.41 \times 10^{-03}$ & 4 \\
\hline \multirow[b]{2}{*}{ as } & January & 1.17 & 31 & 3.27 & 18 & 1.08 & 23 & 1.58 & 13 & 0.75 & 25 & 2.13 & 14 \\
\hline & July & 2.22 & 2 & 2.61 & 0.9 & 0.26 & -5 & 0.26 & -10 & 0.79 & 3 & 0.99 & 1 \\
\hline \multirow[b]{2}{*}{ cs } & January & 1.79 & 2 & 1.89 & -3 & 0.97 & -7 & 0.93 & -8 & 0.32 & -6 & 0.84 & -10 \\
\hline & July & 0.83 & 1 & 1.07 & 2 & 0.23 & -9 & 0.19 & -5 & 0.09 & 3 & 0.18 & 1 \\
\hline
\end{tabular}

* Relative enhancement as a result of simulating realistic HONO
$\left(95-65^{\circ} \mathrm{W}, 30-50^{\circ} \mathrm{N}\right)$ and $(2)$ China $\left(100-130^{\circ} \mathrm{E}, 25-55^{\circ} \mathrm{N}\right)$.

As shown in Figs. 5-7, nitrate aerosols are enhanced only in polluted continental regions (ammonia-rich regions), while only marginally affected or even decreased in all other areas (ammonia-limited environments). Similar to aerosol sulphate, the enhancement in nitrate aerosol mass is dom- inated by the soluble accumulation and coarse modes (Table 3). Since most of the aerosol nitrate in the coastal and marine regions (ammonia-limited) is in the coarse mode, nitrate concentrations in this mode are suppressed owing to the enhancement in the sulphate concentrations 

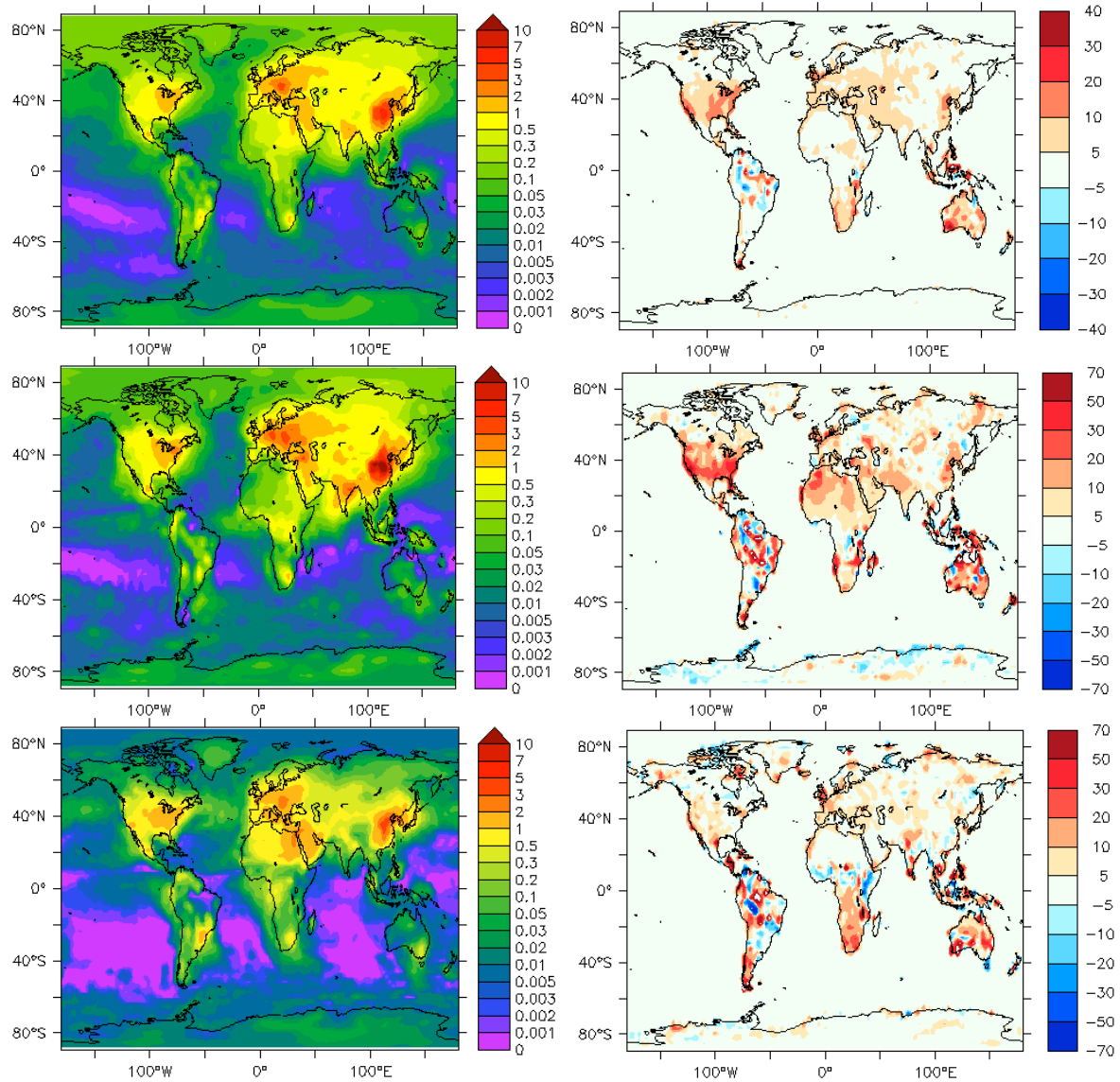

Fig. 8. Simulated aerosol ammonium concentration $\left(\mu \mathrm{g} \mathrm{m}^{-3}\right)$ near the surface for the mean annual (upper panels), boreal winter (January, middle panels) and summer (July, lower panels) conditions and relative changes (in \%, right panels) due to HONO enhancement in the model.

while in the accumulation mode (mostly in continental polluted ammonia-rich environments) they are enhanced. Since $\mathrm{HNO}_{3}$ is most strongly enhanced during winter, nitrate is also mostly enhanced in this season while during summer only relatively small effects are simulated.

\subsubsection{Ammonium}

Ammonium aerosols are largely restricted to the continental regions, with the highest concentrations in the US, Europe, China and India (Fig. 8), mostly due to ammonia $\left(\mathrm{NH}_{3}\right)$ emissions from agriculture. Ammonium aerosols form preferably as ammonium sulphate but also as ammonium nitrate if there is an excess of cations (Pringle et al., 2010). Ammonium aerosol can be enhanced as a result of additional sulphate and nitrate (in high $\mathrm{NO}_{\mathrm{x}}$ regions) only in ammonia-rich regions while in ammonia-limited regions no significant effects are expected. As shown in Fig. 8, the total load of ammonium aerosols is enhanced only in high $\mathrm{NO}_{\mathrm{x}}$, ammonia-rich environments, i.e., mainly in the US, western Europe and eastern Asia. Though ammonia reaches its global maximum levels in India, only small relative ammonium en- hancement occurs in response to HONO induced oxidation due to the relatively low NO levels in this region (see Sect. 4 and e.g., Ojha et al., 2012). The enhancement in ammonium reaches $20 \%$ annually and up to $50 \%$ in winter while in summer the effects are negligible.

\subsubsection{Aerosol number concentrations}

As shown in Fig. 9, the mean near-surface aerosol number concentrations are also significantly enhanced; most apparently in high $\mathrm{NO}_{\mathrm{x}}$ polluted regions with an annual mean relative enhancement over the eastern US and eastern Asia by up to about $70 \%$. Furthermore, the highest relative changes in aerosol number concentrations are simulated during winter months, reaching about $100 \%$ over eastern Asia while during summer almost no enhancements are calculated. The simulated seasonal cycle of aerosol number concentrations in the base run as well as the relative enhancements from simulating realistic HONO over the eastern US and China are shown in Fig. 10, and the absolute differences during summer and winter are shown in Fig. 11. The maximum relative enhancements are simulated in both regions during winter 

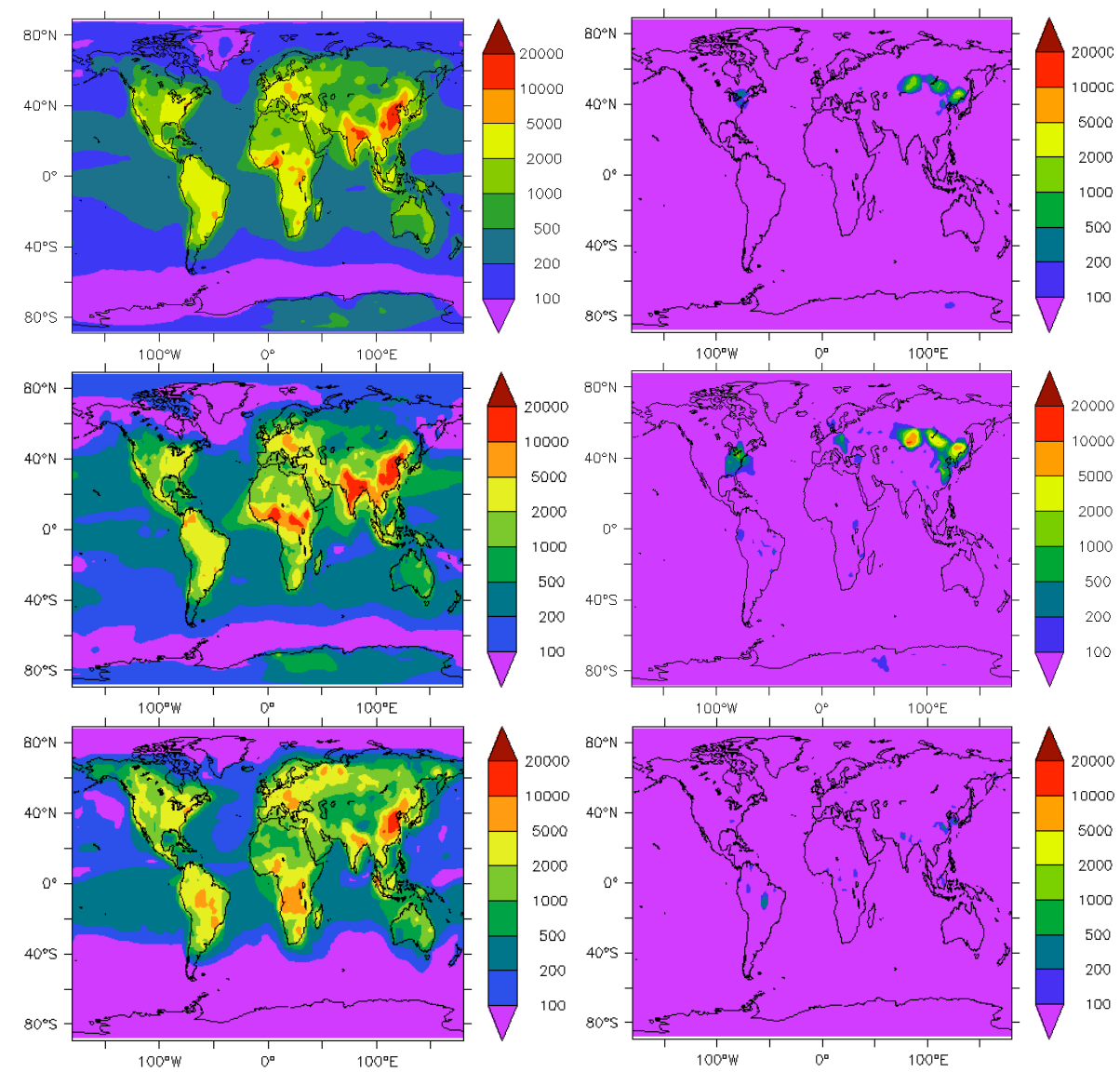

Fig. 9. Simulated mean aerosol number concentrations $\left(\mathrm{cm}^{-3}\right)$ near the surface for the mean annual (upper panels), boreal winter (January, middle panels) and summer (July, lower panels) conditions and the absolute changes (right panels) due to HONO enhancement in the model.

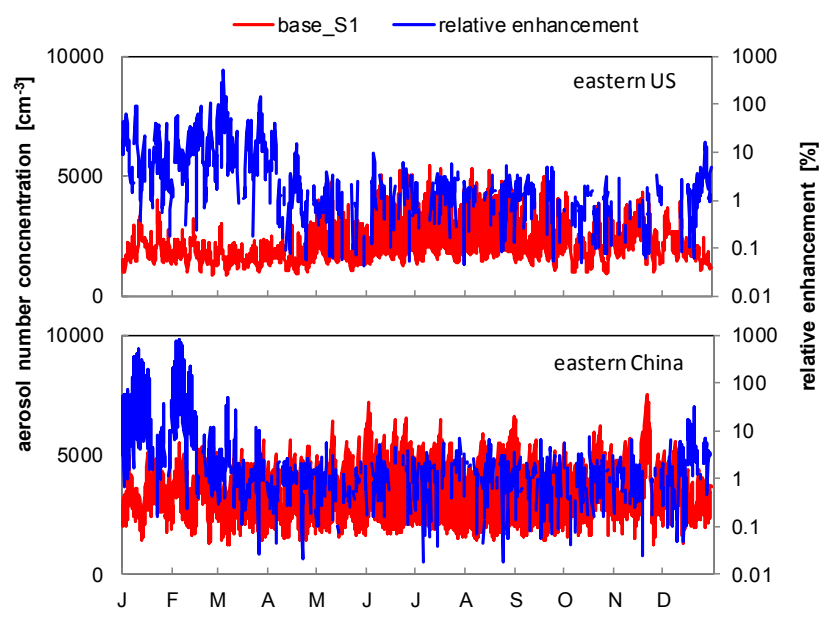

Fig. 10. Simulated aerosol number concentrations and the relative enhancement related to simulating realistic HONO levels near the surface over the eastern US (95-65 $5^{\circ} \mathrm{W}$ and $30-50^{\circ} \mathrm{N}$, upper panels) and China $\left(100-130^{\circ} \mathrm{E}\right.$ and $25-55^{\circ} \mathrm{N}$, lower panels). while during summer the enhancements are again negligible. The increase of aerosol number concentrations over eastern China reaches about $10^{4} \mathrm{~cm}^{-3}$ during January, about one order of magnitude higher than that over the eastern US while during summer enhancements in both regions do not exceed $500 \mathrm{~cm}^{-3}$ (Fig. 11).

The mean simulated aerosol number concentration for the different aerosol modes over the eastern US and China are shown in Table 4. Aerosol number concentrations are dominated by the Aitken and accumulation modes, reflecting typical distributions of the near-surface aerosol number concentrations (see e.g., Pringle et al., 2010, and references therein). The mean relative enhancement in the total aerosol number concentrations over the eastern US and China is about $10-11 \%$ (see Table 4). Another important effect is the transformation from hydrophobic to hydrophilic aerosols related mainly to the enhanced condensation of the gas phase constituents (e.g., $\mathrm{H}_{2} \mathrm{SO}_{4}, \mathrm{HNO}_{3}$ ) as well as the coagulation of the soluble new aerosol particles with the hydrophobic aerosol particles followed by transfer into the hydrophilic mode. For example, over eastern China the particle number concentration in the hydrophobic Aitken (ki) mode is 

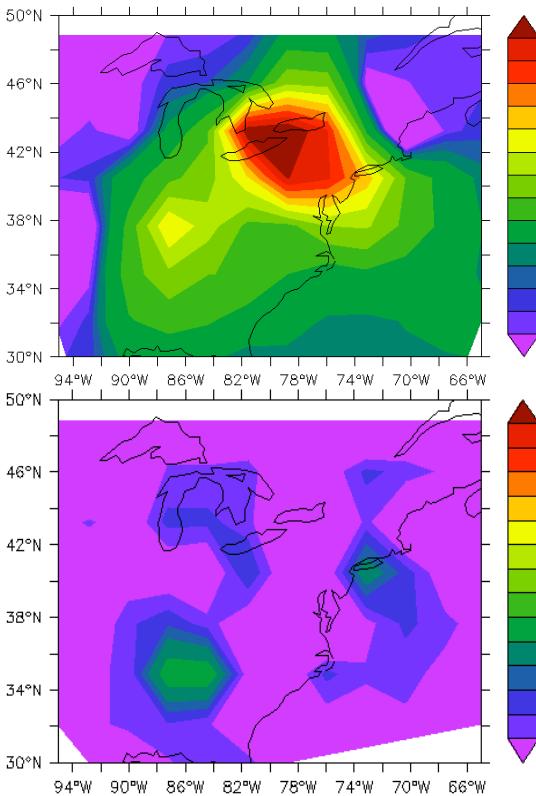

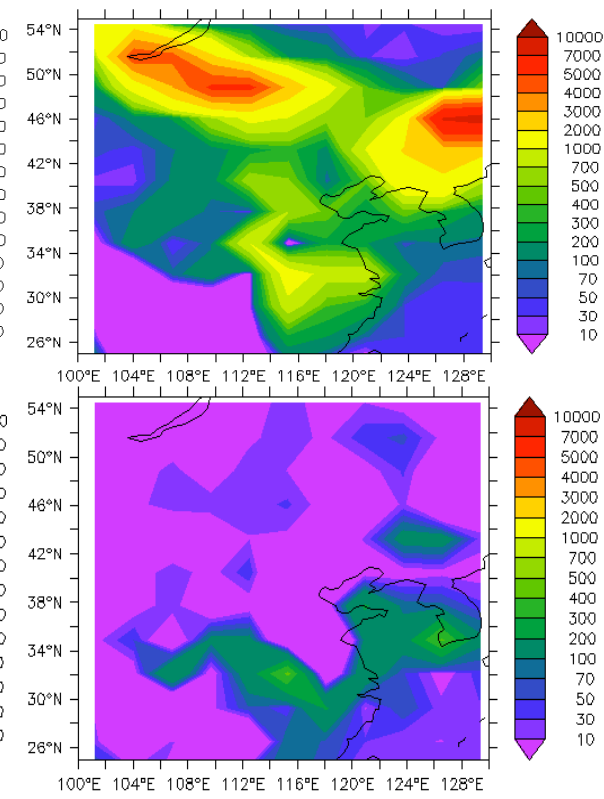

Fig. 11. Simulated monthly mean change in the aerosol number concentrations $\left(\mathrm{cm}^{-3}\right)$ near the surface over the eastern US (left) and China (right) during winter (January, upper panels) and summer (July, lower panels) due to HONO enhancement in the model.

reduced by about $6 \%$ (about $245 \mathrm{~cm}^{-3}$ ) while that of the hydrophilic ks and as modes are enhanced by 31 and $14 \%$, respectively (total about $334 \mathrm{~cm}^{-3}$ ).

Similarly, over the eastern US the hydrophobic Aitken mode particle number is reduced by $13 \%$ (about $161 \mathrm{~cm}^{-3}$ ) while the hydrophilic ks and as modes are enhanced by 44 and $27 \%$, respectively (total about $306 \mathrm{~cm}^{-3}$ ), see Table 4 . In the absence of gas phase $\mathrm{H}_{2} \mathrm{SO}_{4}$, almost no enhancements in the total aerosol number concentrations are calculated as a result of realistic HONO levels. The total enhancement in the aerosol number concentrations can thus be attributed to the strong enhancement in the nucleation mode, especially over eastern China, related mainly to the enhancement in the gas phase sulphuric acid concentration (i.e., nucleation of new particles is calculated in the model as a function of the temperature, relative humidity and the concentration of gas phase $\mathrm{H}_{2} \mathrm{SO}_{4}$, see Pringle et al., 2010).

The enhancement of the aerosol number and solubility implies potential impacts on the cloud nucleation properties and particle lifetime. The enhancement of fine mode aerosol (nucleation, Aitken and accumulation mode) particles, as a result of simulating realistic HONO levels, may directly affect climate by increasing the light scattering and indirectly via altering cloud properties.

\subsection{Comparison with large scale measurements}

A summary of the comparisons between the mean simulated aerosol sulphates, nitrates and ammonium by the base_S1 and S1 model runs and the measurements by CASTNET, EMEP and EANET networks during winter (January to
Table 4. Contributions of the different aerosol modes to the simulated mean aerosol number concentrations and their relative enhancement as a result of simulating realistic HONO levels during January.

\begin{tabular}{|c|c|c|c|c|c|}
\hline \multirow{3}{*}{ aerosol mode } & \multirow{3}{*}{ run } & \multicolumn{4}{|c|}{ aerosol number concentration } \\
\hline & & \multicolumn{2}{|c|}{ eastern US ${ }^{1}$} & \multicolumn{2}{|c|}{ eastern China ${ }^{2}$} \\
\hline & & $\mathrm{cm}^{-3}$ & $\% *$ & $\mathrm{~cm}^{-3}$ & $\% *$ \\
\hline \multirow{2}{*}{ total aerosol } & S1 & 2032 & 10 & 5520 & 11 \\
\hline & S3 & 1956 & -0.3 & 5438 & -0.1 \\
\hline \multirow{2}{*}{ ns } & S1 & 8.51 & 681 & 10.4 & 5131 \\
\hline & S3 & $7.59 \times 10^{-4}$ & 48 & $1.07 \times 10^{-3}$ & -37 \\
\hline \multirow{2}{*}{ ks } & S1 & 552 & 44 & 825 & 31 \\
\hline & S3 & 358 & 2 & 550 & 1 \\
\hline \multirow{2}{*}{ as } & S1 & 235 & 27 & 567 & 14 \\
\hline & S3 & 148 & 1 & 369 & 2 \\
\hline \multirow{2}{*}{ cs } & S1 & 1.40 & 0.6 & 2.61 & -2 \\
\hline & S3 & 1.33 & 0.2 & 2.70 & -4 \\
\hline \multirow{2}{*}{$\mathrm{ki}$} & S1 & 1235 & -13 & 4075 & -6 \\
\hline & S3 & 1448 & -1 & 4472 & -1 \\
\hline \multirow{2}{*}{ ai } & S1 & $5.97 \times 10^{-3}$ & -38 & 33.9 & 2 \\
\hline & $\mathrm{S} 3$ & $1.15 \times 10^{-1}$ & -2 & 39.1 & 2 \\
\hline \multirow{2}{*}{ ci } & S1 & $1.08 \times 10^{-3}$ & -30 & 2.74 & 2 \\
\hline & S3 & $5.73 \times 10^{-3}$ & -1 & 3.10 & 1 \\
\hline
\end{tabular}


Table 5. Summary of the comparison of the base_S1 and S1 model simulations to observations of aerosol concentrations during JanuaryMarch 2001. OAM and MAM are the arithmetic mean of the observations and of the model, respectively, in $\mu \mathrm{g} \mathrm{m}{ }^{-3}$, while OSTD and MSTD are the standard deviation of the observations and model, respectively, in $\mu \mathrm{g} \mathrm{m}^{-3}$. MAM, OAM, MSTD and OSTD represent colocated measurements and model results (i.e., based on the locations of the observations). PF2 is the percentage of modelled point within a factor of two of the observations. RMS denotes the Root-Mean-Square error.

\begin{tabular}{|c|c|c|c|c|c|c|c|c|c|c|c|c|c|c|}
\hline \multirow{2}{*}{ species } & \multirow{2}{*}{ network } & \multirow{2}{*}{ Nr. of stations } & \multirow{2}{*}{ OAM } & \multirow{2}{*}{ OSTD } & \multicolumn{2}{|c|}{$\operatorname{MAM}\left[\mu \mathrm{g} \mathrm{m}^{-3}\right]$} & \multicolumn{2}{|c|}{ MSTD } & \multicolumn{2}{|c|}{ MAM/OAM } & \multicolumn{2}{|c|}{ PF2 [\%] } & \multicolumn{2}{|c|}{ RMS } \\
\hline & & & & & base_S1 & S1 & base_S1 & S1 & base_S1 & S1 & base_S1 & S1 & base_S1 & S1 \\
\hline \multirow{3}{*}{$\mathrm{SO}_{4}^{2-}$} & CASTNET & 53 & 3.17 & 2.17 & 2.57 & 3.05 & 0.75 & 0.93 & 0.81 & 0.96 & 88 & 85 & 1.92 & 1.82 \\
\hline & EMEP & 80 & 2.00 & 1.18 & 2.95 & 3.09 & 1.29 & 1.41 & 1.48 & 1.55 & 73 & 71 & 1.27 & 1.32 \\
\hline & EANET & 11 & 2.82 & 1.73 & 2.89 & 3.13 & 1.70 & 1.96 & 1.03 & 1.11 & 80 & 77 & 2.12 & 2.29 \\
\hline \multirow{3}{*}{$\mathrm{NO}_{3}^{-}$} & CASTNET & 53 & 1.27 & 1.53 & 1.81 & 1.97 & 1.07 & 1.26 & 1.43 & 1.55 & 45 & 45 & 1.71 & 1.81 \\
\hline & EMEP & 27 & 1.75 & 2.16 & 2.24 & 2.42 & 1.00 & 1.19 & 1.28 & 1.38 & 40 & 39 & 2.00 & 1.96 \\
\hline & EANET & 10 & 0.81 & 0.99 & 1.26 & 1.14 & 1.05 & 0.95 & 1.55 & 1.41 & 63 & 63 & 1.68 & 1.59 \\
\hline \multirow{3}{*}{$\mathrm{NH}_{4}^{+}$} & CASTNET & 53 & 1.26 & 0.83 & 1.23 & 1.43 & 0.66 & 0.76 & 0.98 & 1.14 & 86 & 80 & 0.70 & 0.70 \\
\hline & EMEP & 21 & 1.00 & 0.99 & 1.43 & 1.54 & 0.92 & 1.01 & 1.43 & 1.54 & 54 & 51 & 0.87 & 0.90 \\
\hline & EANET & 9 & 0.96 & 0.71 & 0.96 & 1.02 & 0.86 & 0.93 & 1.01 & 1.07 & 66 & 66 & 0.89 & 0.94 \\
\hline
\end{tabular}

March) 2001 are listed in Table 5. As shown in Table 5, simulating realistic HONO levels (S1 simulations) generally increases the mean modelled/measured (MAM/OAM) ratio, most significantly over the US (about $20 \%$ ), thus improving the agreement between modelled and measured sulphate concentrations in this region (i.e., modelled to observed ratio changes from 0.81 to 0.96 ). This is due to the enhanced gas phase oxidation of $\mathrm{SO}_{2}$, being most important over the eastern US, i.e., compared to eastern China (see Sect. 4.1.1 and Table 2). Simulated nitrate by both the base_S1 and S1 runs are generally overestimated with model/measured ratio ranges from 1.28 to 1.55 . These overestimations of nitrate are however related to known issues, including measurement biases, overestimation of sea spray aerosols by GMXe, which may result in overestimation of aerosol nitrate by the uptake of $\mathrm{HNO}_{3}$ (Pringle et al., 2010; de Meij et al., 2012). Over eastern Asia (EANET), the modelled/observed ratio for nitrate decreases from 1.55 for the base_S1 to 1.41 for the $\mathrm{S} 1$ run (i.e., as a result of simulating realistic HONO levels). Ammonium aerosols are well simulated by the reference run over the US and eastern Asia (MAM/OAM are 0.98 and 1.01, respectively) while slightly overestimated over Europe, in agreement with Pringle et al. (2010). The ratio of simulated / measured ammonium aerosol generally follows that of sulphate and increases in the S1 run compared to the reference base_S1, especially over the US. Pozzer et al. (2012) investigated the EMAC simulation results for the years 20052008 and showed also that the model tends to underestimate sulphate aerosol compared to CASTNET and also compared to EMEP and EANET measurements (Pozzer et al., 2012). Furthermore, Pringle et al. (2010) compared simulated concentrations of sulphates, nitrates and ammonium fine mode aerosol $(<1 \mu \mathrm{m}$ diameter) concentrations with aerosol mass spectrometer data and found that the model tends to underestimate the three measured species with sulphates being most poorly captured. Since the HONO enhancements are most significant for the accumulation mode (see Table 3), it can be expected that with realistic HONO simulations, these simulated concentrations are in better agreement with the mass spectrometer measurements. They showed also that the EMAC model tends to overestimate nitrate in coastal regions, which (see Sect. 4.1.2) is more realistically simulated by improving the HONO simulation. Therefore, by accounting for realistic HONO levels the simulated aerosol concentrations are improved compared to measurements.

\section{Conclusions}

In this study the impact of our realistic HONO representation on the simulated aerosol composition has been investigated. By applying our parameterization, simulated HONO mixing ratios typically increase by an order of magnitude, in agreement with our previous study, which showed that this parameterization leads to much better agreement with measurements compared to the model run that only considers the reaction of $\mathrm{NO}+\mathrm{OH}$ as a source of HONO. Owing to the enhanced gas phase $\mathrm{HONO}$ photolysis, $\mathrm{HO}_{\mathrm{x}}\left(\mathrm{OH}+\mathrm{HO}_{2}\right)$ levels are enhanced, thus promoting the formation of organic (e.g., PAN, OVOC) and inorganic $\left(\mathrm{H}_{2} \mathrm{O}_{2}, \mathrm{O}_{3}, \mathrm{HNO}_{3}\right.$ and $\mathrm{H}_{2} \mathrm{SO}_{4}$ ) oxidation products in polluted regions, especially in winter when other photolytic $\mathrm{HO}_{\mathrm{x}}$ sources are of relatively minor importance.

Simulating realistic HONO levels is found to significantly enhance the near surface aerosol sulphate concentrations, mainly due to enhanced gas phase oxidation of $\mathrm{SO}_{2}$ with $\mathrm{OH}$. Nitrate and ammonium are also significantly enhanced in ammonia-rich regions, while in ammonia-limited regions the effect is small. Furthermore, aerosol number concentrations are also significantly higher, accompanied by transfer from the hydrophobic to hydrophilic modes, which is mainly related to the condensation of $\mathrm{H}_{2} \mathrm{SO}_{4}$ on the hydrophobic particles. The enhancement of the aerosol number and solubility 
implies potential impacts on the cloud nucleating properties and the particle lifetime.

The relative enhancements of all species reach a maximum during the winter season while generally being negligible during summer. The simulation results are compared to data from the monitoring networks CASTNET, EMEP and EANET. The model results are in reasonable agreement with measurements and in line with previous evaluations. Simulating realistic $\mathrm{HONO}$ levels was found to enhance the species $\mathrm{SO}_{4}^{2-}, \mathrm{NO}_{3}^{-}$and $\mathrm{NH}_{4}^{+}$, with sulphates being most strongly enhanced, especially over the US, improving the agreement with measurements in this region. The results of the study underscore the importance of HONO for the atmospheric oxidizing capacity and the central role of cloud-aerosol interactions in aerosol formation and growth.

\section{Supplementary material related to this article is available online at http://www.atmos-chem-phys.net/14/ 1167/2014/acp-14-1167-2014-supplement.pdf.}

Acknowledgements. We would like to thank T. Andreae for proofreading the manuscript. The research leading to these results has received funding from the European Research Council under the European Union's Seventh Framework Programme (FP7/2007-2013)/ERC grant agreement no. 226144.

The service charges for this open access publication have been covered by the Max Planck Society.

Edited by: M. Kanakidou

\section{References}

Brühl, C., Lelieveld, J., Crutzen, P. J., and Tost, H.: The role of carbonyl sulphide as a source of stratospheric sulphate aerosol and its impact on climate, Atmos. Chem. Phys., 12, 1239-1253, doi:10.5194/acp-12-1239-2012, 2012.

Charlson, R. J., Langner, J., Rodhe, H., Leovy, C. B., and Warren, S. G.: Perturbation of the Northern Hemisphere radiative balance by backscattering from anthropogenic sulfate aerosols, Tellus, 43, 152-163, 1991.

Charlson, R. J., Schwartz, S. E., Hales, J. M., Cess, R. D., Coakley, J. A., Hansen, J. E., and Hoffman, D. J.: Climate forcing by anthropogenic aerosols, Science, 255, 422-430, 1992.

de Meij, A., Pozzer, A., Pringle, K. J., Tost, H., and Lelieveld, J.: EMAC model evaluation and analysis of atmospheric aerosol properties and distribution, with a focus on the Mediterranean region, Atmos. Res., 114-115, 38-69, doi:10.1016/j.atmosres.2012.05.014, 2012.

Dennis, R. L., Mchenry, J. N., and Barchet, W. R.: Correcting RADM's sulfate underprediction: Discovery and correction of model errors and testing the corrections through comparisons against field data, Atmos. Environ., 27A, 975-997, doi:10.1016/0960-1686(93)90012-N, 1993.
Edgerton, E., Lavery, T., Hodges, M., and Bowser, J.: National dry deposition network: Second annual progress report, Tech. Rep., Environmental Protection Agency, 13127, 1990.

Elshorbany, Y. F., Kurtenbach, R., Wiesen, P., Lissi, E., Rubio, M., Villena, G., Gramsch, E., Rickard, A. R., Pilling, M. J., and Kleffmann, J.: Oxidation capacity of the city air of Santiago, Chile, Atmos. Chem. Phys., 9, 2257-2273, doi:10.5194/acp-92257-2009, 2009a.

Elshorbany, Y. F., Kleffmann, J., Kurtenbach, R., Rubio, M., Lissi, E., Villena, G., Gramsch, E., Rickard, A. R., Pilling, M. J., and Wiesen, P.: Summertime photochemical ozone formation in Santiago, Chile, Atmos. Environ., 43, 6398-6407 doi:10.1016/j.atmosenv.2009.08.047, 2009b.

Elshorbany, Y. F., Kleffmann, J., Kurtenbach, R., Lissi, E., Rubio, M., Villena, G., Gramsch, E., Rickard, A. R., Pilling, M. J., and Wiesen, P.: Seasonal dependence of the oxidation capacity of the city of Santiago de Chile, Atmos. Environ., 44, 5383-5394, doi:10.1016/j.atmosenv.2009.08.036, 2010a.

Elshorbany, Y. F., Barnes, I., Becker, K. H., Kleffmann, J., and Wiesen, P.: Sources and cycling of tropospheric hydroxyl radicals - an overview, Z. Phys. Chem., 224, 967-987, doi:10.1524/zpch.2010.6136, 2010b.

Elshorbany, Y. F., Kleffmann, J., Hofzumahaus, A., Kurtenbach, R., Wiesen, P., Dorn, H.-P., Schlosser, E., Brauers, T., Fuchs, H., Rohrer, F., Wahner, A., Kanaya, Y., Yoshino, A., Nishida, S., Kajii, Y., Martinez, M., Rudolf, M., Harder, H., Lelieveld, J., Elste, T., Plass-Dülmer, C., Stange, G., and Berresheim, H.: $\mathrm{HO}_{\mathrm{x}}$ Budgets during $\mathrm{HO}_{\mathrm{x}}$ Comp: a Case Study of $\mathrm{HO}_{\mathrm{x}}$ Chemistry under $\mathrm{NO}_{\mathrm{x}}$ limited Conditions, J. Geophys. Res., 117, D03307, doi:10.1029/2011JD017008, 2012a.

Elshorbany, Y. F., Steil, B., Brühl, C., and Lelieveld, J.: Impact of HONO on global atmospheric chemistry calculated with an empirical parameterization in the EMAC model, Atmos. Chem. Phys., 12, 9977-10000, doi:10.5194/acp-12-9977-2012, 2012b.

Feichter, J., Kjellstrom, E., Rodhe, H., Dentener, F., Lelieveld, J., and Roelofs, G.-J: Simulation of the tropospheric sulfur cycle in a global climate model, Atmos. Environ., 30, 1693-1707, 1996.

Fortuin, J. P. F. and Kelder, H.: An ozone climatology based on ozone sonde and satellite measurements, J. Geophys. Res., 103, 31709-31734, 1998.

Fountoukis, C. and Nenes, A.: ISORROPIA II: a computationally efficient thermodynamic equilibrium model for $\mathrm{K}^{+}-\mathrm{Ca}^{2+}$ $4 \mathrm{Mg}^{2+}-\mathrm{NH}^{4+}-\mathrm{Na}^{+}-\mathrm{SO}_{4}^{2-}-\mathrm{NO}_{3}^{-}-\mathrm{Cl}^{-}-\mathrm{H}_{2} \mathrm{O}$ aerosols, Atmos. Chem. Phys., 7, 4639-4659, doi:10.5194/acp-7-4639-2007, 2007.

Ganzeveld, L., Lelieveld, J., and Roelofs, G.-J.: A dry deposition parameterization for sulfur oxides in a chemistry and general circulation model, J. Geophys. Res., 103, 5679-5694, 1998.

Gonçalves, M., Dabdub, D., Chang, W. L., Jorba, O., and Baldasano, J. M.: Impact of HONO sources on the performance of mesoscale air quality models, Atmos. Environ., 54, 168-176, 2012.

Harris, E., Sinha, B., van Pinxteren, D., Tilgner, A., Fomba, K. W., Schneider, J., Roth, A., Gnauk, T., Fahlbusch, B., Mertes, S., Lee, T., Collett, J., Foley, S., Borrmann, S., Hoppe, P., and Herrmann: H.: Enhanced role of transition metal ion catalysis during in-cloud oxidation of $\mathrm{SO}_{2}$, Science, 340, 727-730, doi:10.1126/science.1230911, 2013. 
Harris, G. W., Carter, W. P. L., Winer, A. M., Pitts, J. N., Platt, U., and Perner, D.: Observations of nitrous acid in the Los Angeles atmosphere and implications for predictions of ozone-precursor relationships, Environ. Sci. Technol., 16, 414-419, 1982.

Haywood, J. and Boucher, O.: Estimates of the direct and indirect radiative forcing due to tropospheric aerosols: A review, Rev. Geophys., 38, 513-543, doi:10.1029/1999RG000078, 2000.

Hegg, D. A.: The importance of liquid-phase oxidation of $\mathrm{SO}_{2}$ in the atmosphere, J. Geophys. Res., 90, 3773-3779, 1985.

Hjellbrekke, A.-G. and Fjæraa, A. M.: Acidifying and eutrophying compounds and particulate matter, Tech. Rep., Norwegian Meteorological Institute, 13127, 2011.

Intergovernmental Panel on Climate Change, Climate Change 2007: The Physical Science Basis, Cambridge Univ. Press, Cambridge, UK, 2007.

Jeuken, A.: Evaluation of chemistry and climate models using measurements and data assimilation, $\mathrm{PhD}$ thesis, Eindhoven University of Technology, available at: http://www. narcis.nl/publication/RecordID/oai:library.tue.nl:534235, http:// alexandria.tue.nl/extra2/200001283.pdf (last access: 28 January 2014), 2000.

Jimenez, J. L., Canagaratna, M. R., Donahue, N. M., Prevot, A. S. H., Zhang, Q., Kroll, J. H., DeCarlo, P. F., Allan, J. D., Coe, H., Ng, N. L., Aiken, A. C., Docherty, K. S., Ulbrich, I. M., Grieshop, A. P., Robinson, A. L., Duplissy, J., Smith, J. D., Wilson, K. R., Lanz, V. A., Hueglin, C., Sun, Y. L., Tian, J., Laaksonen, A., Raatikainen, T., Rautiainen, J., Vaattovaara, P., Ehn, M., Kulmala, M., Tomlinson, J. M., Collins, D. R., Cubison, M. J., E, Dunlea, J., Huffman, J. A., Onasch, T. B., Alfarra, M. R., Williams, P. I., Bower, K., Kondo, Y., Schneider, J., Drewnick, F., Borrmann, S., Weimer, S., Demerjian, K., Salcedo, D., Cottrell, L., Griffin, R., Takami, A., Miyoshi, T., Hatakeyama, S., Shimono, A., Sun, J. Y., Zhang, Y. M., Dzepina, K., Kimmel, J. R., Sueper, D., Jayne, J. T., Herndon, S. C., Trimborn, A. M., Williams, L. R., Wood, E. C., Middlebrook, A. M., Kolb, C. E., Baltensperger, U., and Worsnop, D. R.: Evolution of organic aerosols in the atmosphere, Science, 326, 1525-1529, doi:10.1126/science.1180353, 2009.

Jöckel, P., Sander, R., Kerkweg, A., Tost, H., and Lelieveld, J.: Technical Note: The Modular Earth Submodel System (MESSy) - a new approach towards Earth System Modeling, Atmos. Chem. Phys., 5, 433-444, doi:10.5194/acp-5-433-2005, 2005.

Jöckel, P., Tost, H., Pozzer, A., Brühl, C., Buchholz, J., Ganzeveld, L., Hoor, P., Kerkweg, A., Lawrence, M. G., Sander, R., Steil, B., Stiller, G., Tanarhte, M., Taraborrelli, D., van Aardenne, J., and Lelieveld, J.: The atmospheric chemistry general circulation model ECHAM5/MESSy1: consistent simulation of ozone from the surface to the mesosphere, Atmos. Chem. Phys., 6, 5067-5104, doi:10.5194/acp-6-5067-2006, 2006.

Jöckel, P., Kerkweg, A., Pozzer, A., Sander, R., Tost, H., Riede, H., Baumgaertner, A., Gromov, S., and Kern, B.: Development cycle 2 of the Modular Earth Submodel System (MESSy2), Geosci. Model Dev., 3, 717-752, doi:10.5194/gmd-3-717-2010, 2010.

Kerkweg, A., Buchholz, J., Ganzeveld, L., Pozzer, A., Tost, H., and Jöckel, P.: Technical Note: An implementation of the dry removal processes DRY DEPosition and SEDImentation in the Modular Earth Submodel System (MESSy), Atmos. Chem. Phys., 6, 4617-4632, doi:10.5194/acp-6-4617-2006, 2006.
Kirkby, J., Curtius, J., Almeida, J., Dunne, E., Duplissy, J., Ehrhart, S., Franchin, A., Gagné, S., Ickes, L., Kürten, A., Kupc, A., Metzger, A., Riccobono, F., Rondo, L., Schobesberger, S., Tsagkogeorgas, G., Wimmer, D., Amorim, A., Bianchi, F., Breitenlechner, M., David, A., Dommen, J., Downard, A., Ehn, M., Flagan, R., Haider, S., Hansel, A., Hauser, D., Jud, W., Junninen, H., Kreissl, F., Kvashin, A., Laaksonen, A., Lehtipalo, K., Lima, J., Lovejoy, E., Makhmutov, V., Mathot, S., Mikkilä, J., Minginette, P., Mogo, S., Nieminen, T., Onnela, A., Pereira, P., Petäjä, T., Schnitzhofer, R., Seinfeld, J., Sipilä, M., Stozhkov, Y., Stratmann, F., Tomé, A., Vanhanen, J., Viisanen, Y., Aron Vrtala, A., Wagner, P., Walther, H., Weingartner, E., Wex, H., Winkler, P., Carslaw, K., Worsnop, D., Baltensperger, U., and Kulmala, M.: Role of sulphuric acid, ammonia and galactic cosmic rays in atmospheric aerosol nucleation, Nature, 476, 429-433, doi:10.1038/nature10343, 2011.

Kulmala, M., Vehkamäki, H., Petäjä, T., Dal Maso, M., Lauria, A., Kerminen, V.-M., Birmili, W., and McMurry, P. H.: Formation and growth rates of ultrafine atmospheric particles: a review of observations, J. Aerosol Sci., 35, 143-176, 2004.

Kulmala, M., Lehtinen, K. E. J., and Laaksonen, A.: Cluster activation theory as an explanation of the linear dependence between formation rate of $3 \mathrm{~nm}$ particles and sulphuric acid concentration, Atmos. Chem. Phys., 6, 787-793, doi:10.5194/acp-6-787-2006, 2006.

Lamsal, L. N., Martin, R. V., van Donkelaar, A., Celarier, E. A., Bucsela, E. J., Boersma, K. F., Dirksen, R., Luo, C., and Wang, Y.: Indirect validation of tropospheric nitrogen dioxide retrieved from the OMI satellite instrument: Insight into the seasonal variation of nitrogen oxides at northern mid latitudes, J. Geophys. Res., 115, D05302, doi:10.1029/2009jd013351, 2010.

Lelieveld, J., Roelofs, G.-J., Ganzweld, L., Feichter, J., and Rodhe, H.: Terrestrial sources and distribution of atmospheric sulphur, Philos. T. R. Soc. Lon. B, 352, 149-158, 1997.

Lelieveld, J., Brühl, C., Jöckel, P., Steil, B., Crutzen, P. J., Fischer, H., Giorgetta, M. A., Hoor, P., Lawrence, M. G., Sausen, R., and Tost, H.: Stratospheric dryness: model simulations and satellite observations, Atmos. Chem. Phys., 7, 1313-1332, doi:10.5194/acp-7-1313-2007, 2007.

Lelieveld, J., Barlas, C., Giannadaki, D., and Pozzer, A.: Model calculated global, regional and megacity premature mortality due to air pollution, Atmos. Chem. Phys., 13, 7023-7037, doi:10.5194/acp-13-7023-2013, 2013.

Li, G., Lei, W., Zavala, M., Volkamer, R., Dusanter, S., Stevens, P., and Molina, L. T.: Impacts of HONO sources on the photochemistry in Mexico City during the MCMA-2006/MILAGO Campaign, Atmos. Chem. Phys., 10, 6551-6567, doi:10.5194/acp-106551-2010, 2010.

Liao, H., Adams, P. J., Chung, S. H., Seinfeld, J. H., Mickley, L. G., and Jacob, D. J.: Interactions between tropospheric chemistry and aerosols in a unified general circulation model, J. Geophys. Res., 108, 4001, doi:10.1029/2001JD001260, 2003.

McHenry, J. N. and Dennis, R. L.: The Relative importance of oxidation pathways and clouds to atmospheric ambient sulfate production as predicted by the regional acid deposition model, J. Appl. Meteorol., 33, 890-905, 1994.

Ménégoz, M., Salas y Melia, D., Legrand, M., Teyssèdre, H., Michou, M., Peuch, V.-H., Martet, M., Josse, B., and DombrowskiEtchevers, I.: Equilibrium of sinks and sources of sulphate 
over Europe: comparison between a six-year simulation and EMEP observations, Atmos. Chem. Phys., 9, 4505-4519, doi:10.5194/acp-9-4505-2009, 2009.

Neitola, K., Brus, D., Makkonen, U., Sipilä, M., Mauldin III, R. L., Kyllönen, K., Lihavainen, H., and Kulmala, M.: Total sulphate vs. sulphuric acid monomer in nucleation studies: which represents the "true" concentration?, Atmos. Chem. Phys. Discuss., 13, 2313-2350, doi:10.5194/acpd-13-2313-2013, 2013.

Ojha, N., Naja, M., Singh, K. P., Sarangi, T., Kumar, R., Lal, S., Lawrence, M. G., Butler, T. M., and Chandola, H. C.: Variabilities in ozone at a semi-urban site in the Indo-Gangetic Plain region: Association with the meteorology and regional process, J. Geophys. Res., 117, D20301, doi:10.1029/2012JD017716, 2012.

Perner, D. and Platt, U.: Detection of Nitrous Acid in the Atmosphere by Differential Optical Absorption, J. Geophys. Res., 6, 917-920, 1979.

Pozzer, A., Jöckel, P., Tost, H., Sander, R., Ganzeveld, L., Kerkweg, A., and Lelieveld, J.: Simulating organic species with the global atmospheric chemistry general circulation model ECHAM5/MESSy1: a comparison of model results with observations, Atmos. Chem. Phys., 7, 2527-2550, doi:10.5194/acp-72527-2007, 2007.

Pozzer, A., Pollmann, J., Taraborrelli, D., Jöckel, P., Helmig, D., Tans, P., Hueber, J., and Lelieveld, J.: Observed and simulated global distribution and budget of atmospheric $\mathrm{C}_{2}-\mathrm{C}_{5}$ alkanes, Atmos. Chem. Phys., 10, 4403-4422, doi:10.5194/acp-10-44032010, 2010.

Pozzer, A., de Meij, A., Pringle, K. J., Tost, H., Doering, U. M., van Aardenne, J., and Lelieveld, J.: Distributions and regional budgets of aerosols and their precursors simulated with the EMAC chemistry-climate model, Atmos. Chem. Phys., 12, 961987, doi:10.5194/acp-12-961-2012, 2012.

Pringle, K. J., Tost, H., Message, S., Steil, B., Giannadaki, D., Nenes, A., Fountoukis, C., Stier, P., Vignati, E., and Lelieveld, J.: Description and evaluation of GMXe: a new aerosol submodel for global simulations (v1), Geosci. Model Dev., 3, 391-412, doi:10.5194/gmd-3-391-2010, 2010.

Roeckner, E., Brokopf, R., Esch, M., Giorgetta, M., Hagemann, S., Kornblueh, L., Manzini, E., Schlese, U., and Schulzweida, U.: Sensitivity of simulated climate to horizontal and vertical resolution in the ECHAM5 atmosphere model, J. Climate, 19, 37713791, 2006.

Roelofs, G. J., Lelieveld, J., and Ganzeveld, L.: Simulation of global sulfate distribution and the influence on effective cloud drop radii with a coupled photochemistry sulfur cycle model, Tellus B, 50, 224-242, 1998.

Roelofs, G. J., Kasibhatla, P., Barrie, L., Bergmann, D., Bridgeman, C., Chin, M., Christensen, J., Easter, R., Feichter, J., Jeuken, A., Kjellstrom, E., Koch, D., Land, C., Lohmann, U., and Rasch, P.: Analysis of regional budgets of sulfur species modeled for the COSAM exercise, Tellus B, 53, 673-694, 2001.

Sander, R., Kerkweg, A., Jöckel, P., and Lelieveld, J.: Technical note: The new comprehensive atmospheric chemistry module MECCA, Atmos. Chem. Phys., 5, 445-450, doi:10.5194/acp-5445-2005, 2005.

Sander, R., Baumgaertner, A., Gromov, S., Harder, H., Jöckel, P., Kerkweg, A., Kubistin, D., Regelin, E., Riede, H., Sandu, A., Taraborrelli, D., Tost, H., and Xie, Z.-Q.: The atmospheric chem- istry box model CAABA/MECCA-3.0, Geosci. Model Dev., 4, 373-380, doi:10.5194/gmd-4-373-2011, 2011.

Sandu, A. and Sander, R.: Technical note: Simulating chemical systems in Fortran90 and Matlab with the Kinetic PreProcessor KPP-2.1, Atmos. Chem. Phys., 6, 187-195, doi:10.5194/acp-6187-2006, 2006.

Schwartz, S. E.: Aqueous-phase reactions in clouds, in: The Chemistry of Acid Rain: Sources and Atmospheric Processes, edited by: Johnson, R. W. and Gordon, G. E., 93-108, American Chemical Society, Symposium Series, Washington D.C., 1987.

Seidl, W. and Dlugi, F.: Modelling of ionic concentrations and sulfate production in cloud droplets: use of published aerosol data, Fresen. J. Anal. Chem., 340, 598-604, 1991.

Seinfeld, J. H. and Pandis, A. N.: Atmospheric Chemistry and Physics, From Air Pollution To Climate Change, 2nd Edn., John Wiley \& Sons, Inc., Hoboken, New Jersey, 2006.

Shen, X.: Aqueous phase sulphate production in clouds at mt. Tai in eastern China, thesis, Colorado State university, US, http://digitool.library.colostate.edu/R/?func=dbin-jump-full $\backslash$ \&object_id=127482l\&local_base=GEN01, 2011.

Sun, Y. L., Wang, Z. F., Fu, P. Q., Yang, T., Jiang, Q., Dong, H. B., Li, J., and Jia, J. J.: Aerosol composition, sources and processes during wintertime in Beijing, China, Atmos. Chem. Phys., 13, 4577-4592, doi:10.5194/acp-13-4577-2013, 2013.

Tost, H., Jöckel, P., Kerkweg, A., Sander, R., and Lelieveld, J.: Technical note: A new comprehensive SCAVenging submodel for global atmospheric chemistry modelling, Atmos. Chem. Phys., 6, 565-574, doi:10.5194/acp-6-565-2006, 2006.

Tost, H., Jöckel, P., Kerkweg, A., Pozzer, A., Sander, R., and Lelieveld, J.: Global cloud and precipitation chemistry and wet deposition: tropospheric model simulations with ECHAM5/MESSy1, Atmos. Chem. Phys., 7, 2733-2757, doi:10.5194/acp-7-2733-2007, 2007.

Tost, H. and Pringle, K. J.: Improvements of organic aerosol representations and their effects in large-scale atmospheric models, Atmos. Chem. Phys., 12, 8687-8709, doi:10.5194/acp-12-86872012, 2012.

Totsuka, T., Sase, H., and Shimizu, H.: Major activities of acid deposition monitoring network in East Asia (EANET) and related studies, in: Plant Responses to Air Pollution and Global Change, edited by: Omasa, K., Nouchi, I., and DeKok, L. J., SpringerVerlag, Tokyo, doi:10.1007/4-431-31014-2_28, 251-259, 13127, 2005.

van Aalst, M. K., van den Broek, M. M. P., Bregman, A., Brühl, C., Steil, B., Toon, G. C., Garcelon, S., Hansford, G. M., Jones, R. L., Gardiner, T. D., Roelofs, G. J., Lelieveld, J., and Crutzen, P. J.: Trace gas transport in the 1999/2000 Arctic winter: comparison of nudged GCM runs with observations, Atmos. Chem. Phys., 4, 81-93, doi:10.5194/acp-4-81-2004, 2004.

Van den Berg, A., Dentener, F. J., and Lelieveld, J.: Modelling the chemistry of the marine boundary layer: Sulfate formation and the role of sea-salt aerosol particles, J. Geophys. Res., 105, 11671-11698, 2000.

Venkataraman, C., Mehra, A., and Mhaskar, P.: Mechanisms of sulphate aerosol production in clouds: effect of cloud characteristics and season in the Indian region, Tellus B, 53, 260-272, 2001.

Vignati, E., Wilson, J., and Stier, P.: M7: an efficient size resolved aerosol microphysics module for large-scale 
aerosol transport models, J. Geophys. Res., 109, D22202, doi:10.1029/2003JD004485, 2004.

World Health Organization: World health report 2002, technical report, Geneva, Switzerland, 2002.

Zhang, L., Jacob, D. J., Knipping, E. M., Kumar, N., Munger, J. W., Carouge, C. C., van Donkelaar, A., Wang, Y. X., and Chen, D.: Nitrogen deposition to the United States: distribution, sources, and processes, Atmos. Chem. Phys., 12, 4539-4554, doi:10.5194/acp-12-4539-2012, 2012.
Zhang, R., Sarwar, G., Fung, J. C. H., Lau, A. K. H., and Zhang, Y.: Examining the impact of nitrous acid chemistry on ozone and PM over the Pearl River Delta Region, Advances in Meteorology, 2012, 140932, doi:10.1155/2012/140932, 2012. 